\title{
KACHLOVÉ SOUBORY Z FRÝDKU
}

\section{MARKÉTA TYMONOVÁ}

\begin{abstract}
Abstrakt: Článek představuje dva kachlové celky ziskané z areálu frýdeckého zámku (1975, 1995) a ze severni strany historického jádra města (2003), kde byla zjištěna střepová deponie indikujici přitomnost hrnčirrské dilny. Protože se v odpadních objektech pod zámeckým návrším našly kachle s podobnou výzdobou jako na zámku, je možné, že se zde v 16. a na počátku 17. století kromě kuchyňské a stolni keramiky mohlo vyrábět i kamnářrské zboží.
\end{abstract}

Klíčová slova: zámek ve Frýdku - hrnčǐrský odpad-renesanční kachle-raný novověk.

\section{Tile Series from Frýdek}

Abstract: This article presents two series of tiles, from the Frýdek chateau (acquired in 1975 and 1995) and from the north side of the historical centre of the town (2003) where sherds indicated the presence of a potter's workshop. As the waste features below the chateau hill yielded tiles with similar decoration as seen on those from the chateau, it is possible that stove tiles were made there, along with kitchenware and tableware, in the 16th century and in the early 17th century.

Key words: Frýdek chateau - pottery waste - Renaissance tiles - early modern age.

\section{Úvod}

Architektonické památky jsou významným dokladem stavebního vývoje profánních a sakrálních objektů, které příslušníci vyšších sociálních vrstev využívali k sídelním, hospodářským a kultovním účelům. Jejich funkci naznačovala nejen terénní dispozice a charakter zástavby, nýbrž také pozůstatky interiérového vybavení, jež spolu s dalšími movitými památkami vypovídají o každodenním životě tamních obyvatel. V př́ípadě zeměpanských a šlechtických sídel se do charakteru stavby kromě vojenských aspektů promítalo i hledisko reprezentační, kladoucí důraz na rodovou prestiž, společenské postavení nebo náboženské vyznání. Jejich symbolickou rovinu zhmotňovala nejen malířská či sochařská výzdoba, ale od 14. století také ikonografie kachlových kamen, v nichž se skloubila účelnost s estetickou funkcí. Využívání tohoto efektivního a bezpečného zdroje tepla však limitovala řada faktorů, jako byla omezená životnost, módní trendy a v neposlední řadě i technologické inovace, v jejichž důsledku docházelo k výměně dosluhujícího otopného zařízení.

Kamnářská sut' z funkčně či vzhledově nevyhovujících kamnových těles se likvidovala různě. V areálech panských sídel se zpravidla vysypávala do hradních př́ikopů a ve městech do odpadních jam, jak na to poukazuje situace zjištěná ve slezském Frýdku, situovaném v jižní části bývalého těšínského knížectví (obr. 1). Z prostoru zámeckého kopce pochází několik kachlových souborů - dva př́mo ze zámku a třetí z parcel pod jeho severním okrajem, kde byla kromě vyhozených kachlů zjištěna i deponie odpadu z hrnčířské dílny obsahující kuchyňskou a stolní novověkou keramikou z 16.-19. století. Protože se některé kamnářské výrobky podobaly exemplářum ze zámku, vyvstala otázka, zda v těchto místech nepracovala dílna, která do svého výrobního repertoáru zařadila také výrobu kachlů. Tato hypotéza se však zatím plně nepotvrdila, poněvadž nalezené kusy nesly stopy použití (očazení, mazanice), takže nešlo o „čerstvé“ dílenské výrobky a mimo to odsud scházely průkaznější doklady výrobní činnosti v podobě polotovarů (čelní desky, komory), defektních výrobků, pracovních nástrojů (kadluby) nebo výrobních objektů (pec s vsázkou). I když žádným z těchto „důkazů“ dosud nedisponujeme, produkci v těchto místech zcela vyloučit nemůžeme i proto, že v obou souborech se vyskytly identické kachle v režném i glazovaném provedení, které by mohly dílenskou činnost indikovat. 


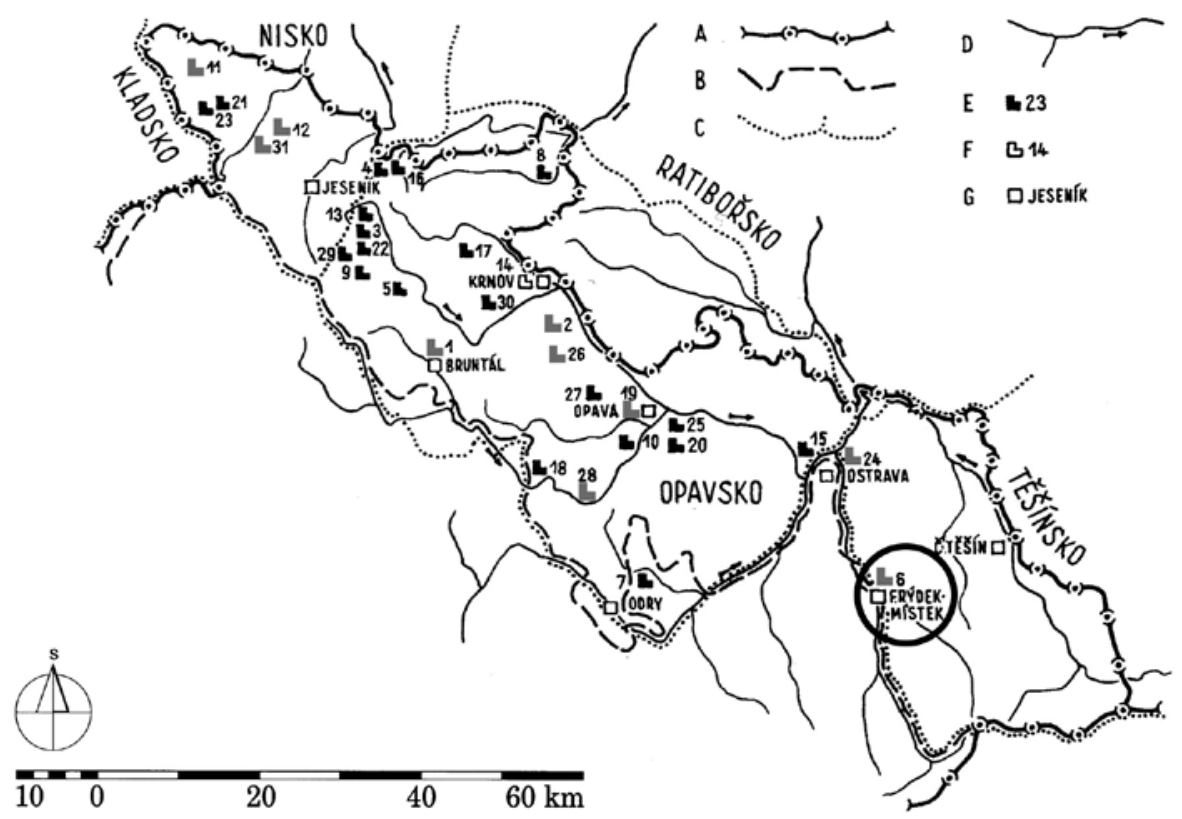

Obr. 1. Mapa českého Slezska s vyznačením polohy frýdeckého hradu. A - dnešní hranice; B - historická hranice Čech; C - hranice stř̌edověkých knížectví; D - vodní toky; E - hrad; F - městský hrad; G - orientační body. Podle Kouřil-PrixWihoda 2000, 15, upraveno.

Abb. 1. Karte von Tschechisch-Schlesien mit eingezeichneter Lage des Friedeker Schlosses. A - heutige Grenze; B - historische Grenze Böhmens; C - Grenze des mittelalterlichen Herzogtums; D - Wasserläufe; E - Burg; F - Stadtburg; G - Orientierungspunkte. Nach Kouřil-Prix-Wihoda 2000, 15, modifiziert.

\section{Dějiny hradu a města}

Vznik opevněného sídla situovaného na západní straně frýdeckého náměstí je spojován s předlokační osadou Jannutha, jmenovanou v soupise desátků vratislavského biskupství (1303-1306), která bývá ztotožňována s Jamnicí (Jemnicz), zmiňovanou spolu s tvrzí v listinách potvrzujících lenní svazek knížete Kazimíra I. († 1358) s českým králem Janem Lucemburským v roce 1327. Zmíněné opevnění je považováno za předchůdce hradu zbudovaného těšínskými Piastovci mezi lety 1327 a 1339 na pravém břehu Ostravice kvůli zajištění moravsko-slezského pomezního území, kudy procházela důležitá obchodní cesta směrem na Těšín a polský Krakov (Bakala 1971; 1982, 41-42; 2005, 14-16; Boris 1981, 15; Kouřil-Prix-Wihoda 1997, 258; Žáček 1998, 152; Juřák 2002, 7; Al Saheb 2004, 81-82; Vojkovský 2007, 2; Korbelářová-Žáček 2008, 33; Pastorek 2011, 8-10; Jež 2012, 154; 2014, 33-37; Vojkovská 2012, 154).

Existenci městečka vyrostlého ve východním předpolí fortifikace nepřímo dokládá listina z 10. záŕí 1339, v níž byl jmenován vratislavský kněz Mikuláš z Frýdku, jehož predikát (de Fredek) uchoval název sídla, které až do roku 1573 plnilo funkci správního centra frýdeckého panství (Kouřil-Prix-Wihoda 2000, 111; Čapský 2011, 41; Jež 2014, 36). Strážní funkce pohraničního opevnění posazeného na okraj prudce se svazující ostrožny zdánlivě pozbyla opodstatnění $\mathrm{v}$ roce 1402, kdy se Frýdecko sloučilo s místeckým lénem na protilehlém břehu Ostravice, které odkoupil se svolením Kazimírova syna Přemysla I. († 1410) od Lacka a Voka z Kravař tehdejší zástavní držitel Frýdecka Sobek z Kornic (Žáček 1986, 30-31; Pindur 2004, 36, 56-57; 2005, 10; Al Saheb 2014, 45; Jež 2014, 37).

Těšínská knížata na frýdeckém hradě trvale nesídlila, k tomu využívala rezidenční Těšín, ale strategická poloha nad Ostravicí nabyla na významu za husitských válek, kdy Zikmundův straník Boleslav I. († 1431) nechal sídlo zrenovovat (obr. 2). Avšak značné finanční výdaje navýšené o náklady na přestavbu těšínského a bílského hradu vyčerpaly knížecí pokladnu natolik, že 


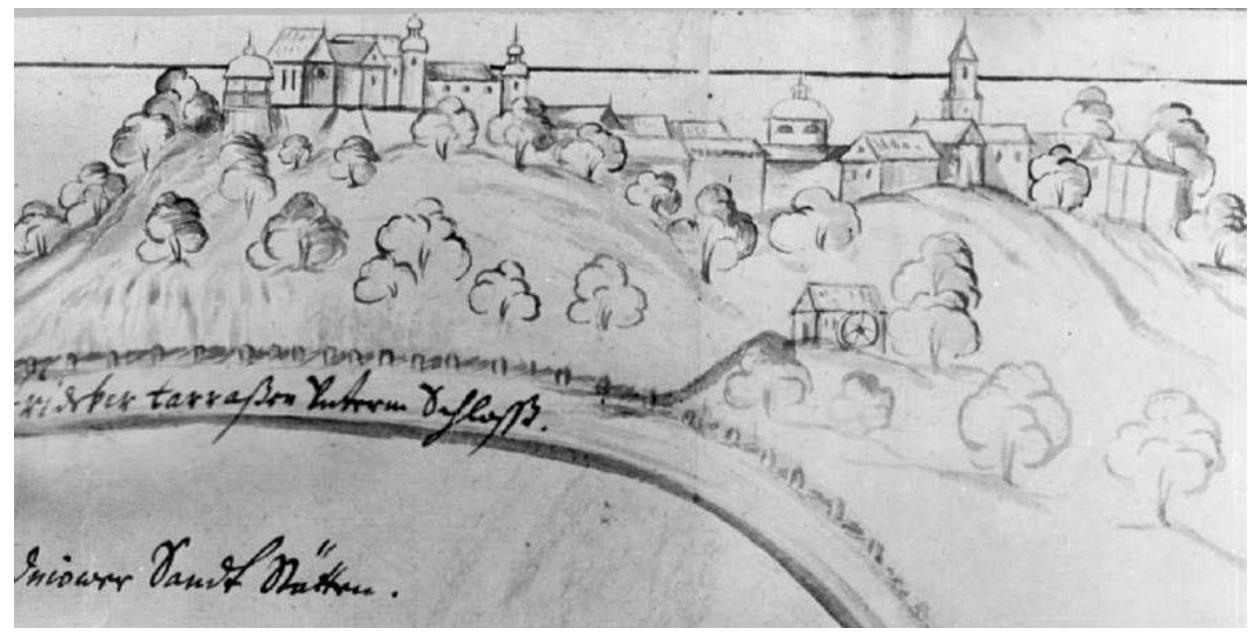

Obr. 2. Frýdek. Veduta se zámkem a městem s věží kostela sv. Jana Křtitele na mapě hraničních sporů o řeku Ostravici z roku 1695. Zdroj Ústřední ředitelství arcibiskupských statků Kroměříž (inv. č. 53788, Mapy a plány, poř. č. 139, svazek II/1-1442), uloženo v ZAO, pracoviště Olomouc.

Abb. 2. Friedek. Stadtansicht mit Schloss und Stadt mit Kirchturm der Kirche Johannes der Täufer auf einer Karte mit Grenzstreitigkeiten um den Fluss Ostrawitza aus dem Jahr 1695. Quelle Zentraldirektorium der erzbischöflichen Güter Kroměříž (Inv.-Nr. 53788, Karten und Pläne, Akquisitionsnr. 139, Band II/1-1442), aufbewahrt im Landesarchiv in Opava, Zweigstelle Olmütz.

jeho čtyři nedospělí synové (Václav I., Vladislav, Boleslav II. a Přemysl II.) byli donuceni panství v roce 1434 zastavit Arnoštu Tvorkovskému z Polské (Slezské) Ostravy a následně v letech 1437-1449 Mikuláši z Dubovce. Zadlužené statky se posléze nakrátko vrátily do prŕmé držby Boleslava II. († 1452), ale ten si Frýdek neponechal a převedl jej na svou manželku Annu jako věnnou zástavu. V roce 1463 převzal frýdecko-místecké panství Přemysl II. († 1477), jenž nabyté statky roku 1471 opět zastavil Janu Buřejovi z Klvova (Jež 2007, 21; 2009b, 38; 2014, 53). Když se o tři léta později ujal vlády Přemyslův synovec Kazimír II. († 1528), knížecí majetky v roce 1492 znovu vykoupil a pozdně gotické sídlo ve Frýdku nechal renesančně zadaptovat. Finanční tíseň jej však donutila k dalším zástavám (Jan Labut' ze Křtin a jeho syn Vladko, Jan Trnka z Ratibořan), a ačkoli dlužné pohledávky posléze vyplatil, hospodářský propad tím nezastavil (Žáček 1986, 49-50; Kouřil-Prix-Wihoda 2000, 111-112; Pindur 2004, 36; Vojkovský 2007, 4-8; Weissbrod 2009, 16-17; Korbelářová-Žáček 2008, 70-77; Jež 2014a, 54).

Po předčasné smrti Kazimírova druhorozeného syna Václava II. († 1524) se novým zástavním držitelem frýdecko-místeckého zboží nakrátko stal nejvyšší komorník Českého království Jaroslav ze Šelmberka se syny Jiřím a Jaroslavem a od roku 1528 kališnicky orientovaný magnát Jan z Pernštejna († 1548), který byl ustanoven poručníkem Kazimírova nezletilého vnuka Václava III. Adama († 1579; Jež 2008, 225-267; 2008a, 6; 2009, 18-20; 2014a, 54-55). V roce 1540 se poručnický vztah změnil v př́íbuzenský, když se Pernštejnova dcera Marie († 1566) provdala za mladého knížete. Ten se po dosažení plnoletosti ujal v roce 1545 samostatné vlády, ale panství na březích Ostravice ponechal bývalému poručníkovi v zástavě, aby tak umořil půjčky, jejichž splacení urgovali Pernštejnovi synové (Turková 2005, 22-24). Dluhy způsobené špatným hospodařením a nákladným životním stylem brzy nestačily krýt ani další zástavy (Jiří Čelo z Čechovic - 1552, Burian Barský z Barště - 1554 aj.). Poté, co narostly do výše téměř čtvrt milionu tolarů, musel Václavův syn Fridrich Kazimír († 1571) v roce 1573 frýdecko-místecké, fryštátské a bílské zboží prodat Matyáši a Jiřímu z Lohova a Staré Vsi (Jež 2007, 89, 96, 100, 113, 116; 2009b, 148-149; 2014a, 57; Kotásek 2008, 28-29; Korbelářová-Žáček 2008, 113-114). Prodejem se panství vyčlenilo z dědičných statků těšínských Piastovců a stalo se samostatným stavovským panstvím (status minor) s vrchnostenskou správou podléhající přímo českému králi (Kouřilová 2002, 15; Kroček 2002, 1; Korbelářová-Žáček 2008, 113-114; Jež 2014a, 51). 
Páni z Lohova zakoupené zboží dlouho nevlastnili a rok před prodejem panství olomouckému biskupu Stanislavu II. Pavlovskému z Pavlovic nechali pořídit urbář (1580) se soupisem veškerého majetku (Sobotík-Grobelný 1953, 118; Žáček 1986, 49; 1992, 34-35; Kotásek 2008, 30; Vojkovský 2007, 10; Weissbrod 2009, 33). Nový vlastník po čtyřech letech panství rozdělil na část místeckou (moravskou), kterou připojil k hukvaldskému církevnímu dominiu a frýdeckou (slezskou), kterou prodal nejvyššímu sudímu opavského knížectví Bartoloměji Bruntálskému z Vrbna († 1604). Tento prŕslušník významného panského rodu nechal hrad opět přestavět a na rozdíl od předchůdců se v něm usadil se svou manželkou Annou, rozenou Vyškotovou z Vodník († 1606). Po manželově smrti odkázala bezdětná vdova Frýdek Bartolomějovým synovcům Václavovi a Janovi (Pindur 2005, 10-11; Jež 2009, 21; 2014a, 59; Výtisk 2012, 38; Janišová 2014, 65), ale první brzy zemřel a druhý byl zabit 18. záŕí 1620 v lese u Chlebovic, když se vracel z Nového Jičína (Žáček 1986, 51; Tichánek 2005, 91; Juřák 2011, 9; Jež 2014a, 59-60; Al Saheb 2014, 86).

Na počátku třicetileté války se Janova vdova Alžběta Kateřina Sedlnická z Choltic († 1632) na čas přestěhovala na bezpečnější Hukvaldy, což bylo prozíravé, jelikož v roce 1626 frýdecký zámek i město vydrancovala sasko-dánská vojska. Paní Kateřina se pak opět provdala, za Karla Zdeňka Žampacha z Potštejna, ale její majetky v roce 1636 zdědil postižený syn z prvního manželství Jan mladší Bruntálský z Vrbna († 1642). Panství v té době bylo tak zadlužené, že bylo prodáno ve veřejné dražbě největšímu věřiteli Jiřímu z Oppersdorfu († 1651), který za tímto účelem nechal v roce 1636 pořídit nový urbár. S jeho érou je spojeno další zvelebování zámku, který byl v letech 1638-1644 rozšířen o jednopatrové raně barokní křídlo zbudované ve východním předzámčí na místě zasypaného příkopu. Ve stavebních aktivitách pokračoval i Jiřího syn Matyáš Rudolf († 1666), za něhož spravoval panství jako poručník hrabě Jan Bernard Pražma z Bílkova. Dílčí úpravy prováděl také Matyášův nevlastní bratr František Eusebius († 1691), kterého císař Leopold I. jmenoval císařským tajným radou (Žáček 1995, 1; Al Saheb-Pindur 2005, 6; Weissbrod 2009; 31-33, 44, 48-50; Jež 2014a, 60-62; Pindur 2014, 106-108).

V roce 1688 zachvátil Frýdek velký požár, který poškodil jak zámek, tak město. Nebyla to však jediná událost tohoto druhu, protože oheň řádil i v předchozích letech, 1592 a 1607, kdy způsobil nemalé škody na zámeckých i městských nemovitostech. Spolu s ničivými důsledky třicetileté války inicioval odstraňování staré dřevohlinité zástavby, kterou postupně nahradily kamenné domy (Jež 2014a, 69, 71). Kromě živelných pohrom urbanizaci Frýdku ovlivnila také specifická terénní situace, která městu vtiskla typický oválný půdorys, příznačný pro slezskotěšínská města, jako byl Fryštát či Bílko. Ústředí tohoto původně zeměpanského centra tvořilo obdélné náměstí s tržištěm, obklopené ze tří stran právovárečnými domy a zámkem, do něhož vstupovala hlavní cesta od severu přes Lískoveckou bránou (1549; Leskoveckou) stojící ve spodní části Hluboké ulice a vycházela na východní straně skrze bránu Horní (1556; Bruzovská, Těšínská) v místě křížení ulic Radniční a Těšínské (obr. 3). Od poloviny 14. století, kdy začala před branami vyrůstat předměstí, bylo vnitřní město opevněno - vůči hradu příkopem a valem a v ostatních úsecích městskou zdí (1423), která na severovýchodní straně obíhala kolem farního kostela sv. Jana Křtitele (1447). Na protilehlé straně náměstí stála budova radnice, zakoupená v roce 1545 , kde se až do roku 1630 scházela městská rada. Poblíž zámku se nacházel městský pivovar a lázně a mimo centrum další městské provozovny: dvůr, mlýny, valcha a cihelna zřízená nově za Oppersdorfů na východní straně města (Al Saheb-Pindur 2008, 176; Jež 2014, 67-68; Lachová 2015, 48-49).

$\mathrm{V}$ polovině 15. století př́íslušelo k Frýdku deset vsí Místkem počínaje, ale později v roce 1580 , kdy panství čítalo přibližně 5000 lidí, to již bylo 23 vesnic. Ve městě o 163 osedlých domech, z čehož bylo 84 šenkovních, žilo odhadem 1200 až 1600 obyvatel. Původně se zde pořádaly tř́ jarmarky (1463), později čtyři (1611) a další královské výnosy jejich počet zvýšily na šest. Hospodářská základna, podobně jako u jiných měst, spočivala na obchodu a řemeslné výrobě organizované od první poloviny 15 . století v ceších. V listině Boleslava I. z roku 1423 ještě nebyly cechovní spolky blíže specifikovány, ale v roce 1545 jsou doloženi ševci, 1509 soukeníci, 1541 kloboučníci a solaři atd. Podle prvního urbáře z roku 1580 měli svůj samostatný cech soukeníci (63 mistrů), ševci (16), kováři (8) a řezníci (7). Hrnčíři, kteří tehdy nebyli nikterak početní („sú čtyre“), vlastní organizaci neměli a každý týden museli na zámek dodávat „,hrnců za 4 groše“. V druhém urbáři 


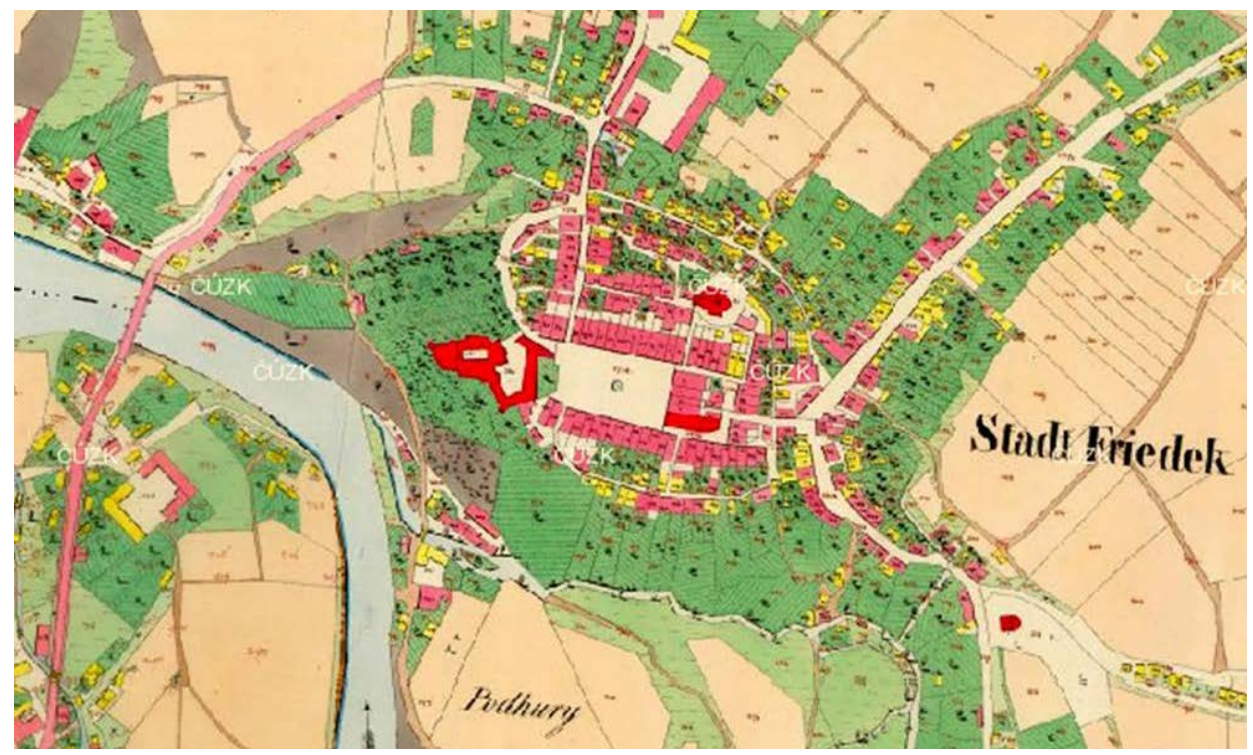

Obr. 3. Frýdek. Poloha zámku a půdorys historického jádra města na mapě stabilního katastru z roku 1836. Zdroj databáze Ústředního archivu zeměměřictví a katastru.

Abb. 3. Friedek. Lage des Schlosses und Grundriss des historischen Stadtkerns auf einer Karte des Stabilen Katasters aus dem Jahr 1836. Quelle Datenbank des Zentralen Archivs für Landesvermessung und Kataster.

z roku 1636, kdy k Frýdku s 195 osedlými příslušelo 20 vsí, byli zmíněni pouze tři hrnčíři, z nichž každý musel týdně odvádět za groš hrnců nebo jiného hrnčířského díla (Sobotík-Grobelný 1953, 20-22; Jež 2014a, 68-76; Žáček 1995, 2). Je otázkou, zda se v pravidelně odváděných dávkách mohly skrývat i kachlové výrobky, jejichž použité fragmenty se našly v odpadových deponiích vhozených do zámeckého př́kopu a do jam u hradby na severní straně města.

\section{Nálezové okolnosti}

Kachlové celky z frýdeckého zámku pochází ze dvou záchranných akcí, které provedli pracovníci Muzea Beskyd při úpravách prvního nádvoří v roce 1975, kdy se před průčelím průjezdní brány hloubila nová kanalizace, a v roce 1995, když se vstupní prostor kompletně předlažd’oval (obr. 4, 5:1, 2). Starší akce, při níž byl před bránou do jižního křídla odhalen mostní (?) oblouk, byla zdokumentována pouze fotograficky. Druhá byla archeologicky sledována Zuzanou Břízovou, která v sondě uprostřed nádvoří (S3) zachytila okraj hradního př́íkopu, jenž původně chránil gotické jádro, indikované zdivy na druhém nádvoří (1975) a v suterénu pod schodištěm do Zámeckého klubu (1981), kde se našla keramika ze 13. (?) až 15. století. Zásyp téměř $5 \mathrm{~m}$ hlubokého př́ikopu obtáčejícího jihovýchodní a severovýchodní nároží tvořil odspodu násyp stavební destrukce s vápnem a kameny, překrytý vrstvou cihel s kuchyňskou keramikou a fragmenty kachlů, na niž nasedala černá vrstva promíšená sazemi, popelem, zbytky kamnářské mazanice a kachlových zlomků. Evidentně šlo o materiál z několikerých vyhozených kamen, jehož starší složka souvisela se stavebními úpravami za knížete Kazimíra II. na přelomu 15. a 16. století a mladší s rekonstrukcemi Bruntálských z Vrbna na konci 16. a počátku 17. století, které aktivoval požár v roce 1607. Oba nálezové celky obsahovaly řadu identických jedinců, protože byly ve stejnou dobu vyhozeny do obranného př́íkopu, k jehož zasypání došlo před výstavbou oppersdorfského křídla (1638-1644), zbudovaného na nezastavěné parcele zakoupené k tomuto účelu v roce 1638 od měštana Jana Bučka (Boris-Žáček 1981, 1; Kouřil 1983, 56; Břízová 1996, 2-10; Krut'ová 1998, 34-39; Al Saheb-Pindur 2005, 6; Weissbrod 2009, 17, 21, 35; Tymonová 2011, 71; Jež 2014, 38; Holcová 2015, 12-18). 


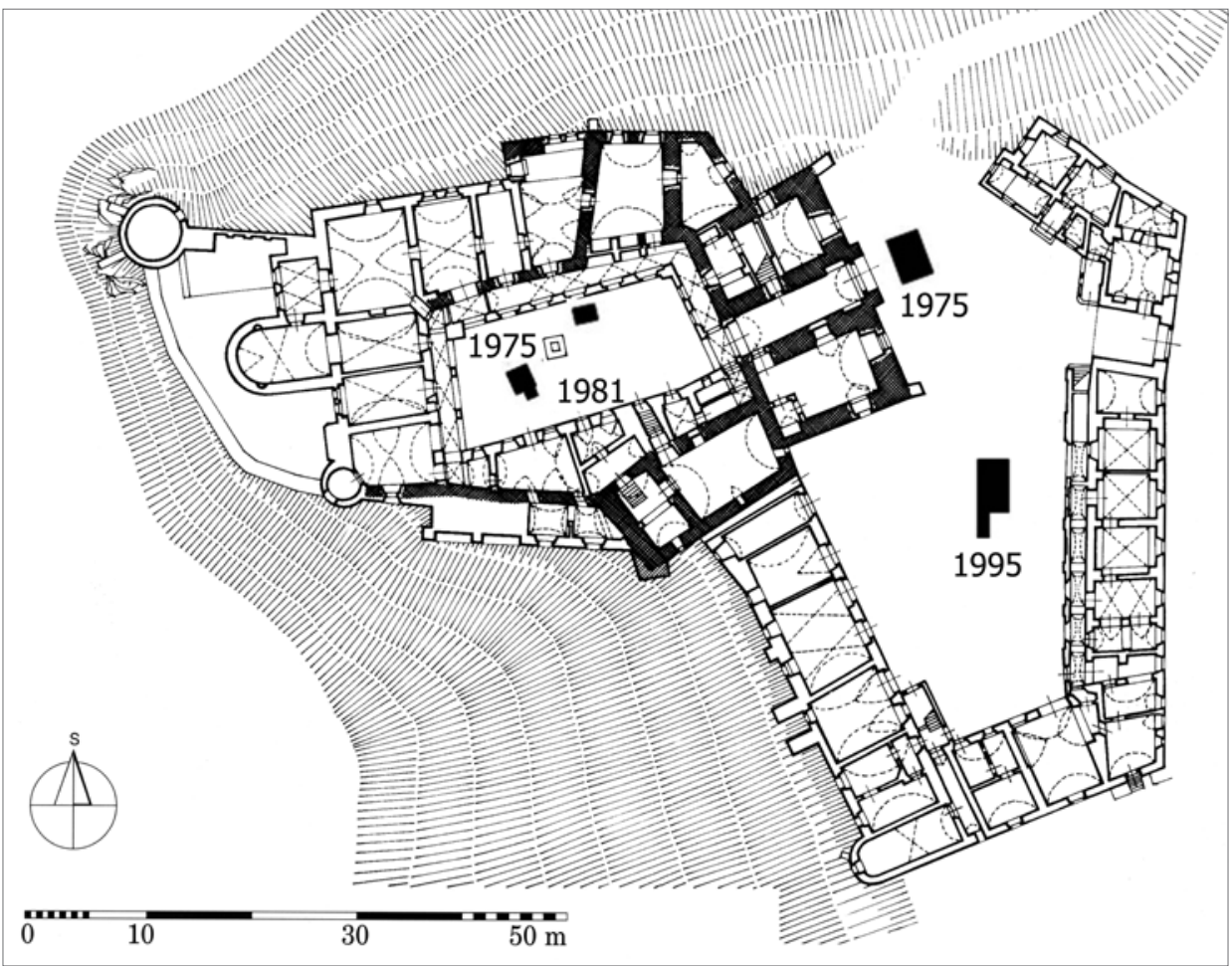

Obr. 4. Frýdek. Půdorys frýdeckého hradu s vyznačením polohy nálezů zjištěných v roce 1975, 1981 a 1995. Podle KouřilPrix-Wihoda 2000, 114, upraveno.

Abb. 4. Friedek. Grundriss der Friedeker Burg mit eingezeichneter Lage der im Jahr 1975, 1981 und 1995 gemachten Funde. Nach Kouřil-Prix-Wihoda 2000, 114, modifiziert.

Kachlový soubor pocházející ze severní strany města zachránili pracovníci opavské pobočky NPÚ ÚOP v Ostravě v roce 2003 na staveništi obchodního centra Kaufland mezi Masarykovou tř́́dou a ulicemi Hlubokou a Na Blatnici (obr. 5:3). Na zkoumané ploše odkryli odpadní jámy hluboké okolo dvou metrů, které byly umístěny v zadních traktech parcel přiléhajících ke zbytku gotického opevnění, zjištěného již v roce 2001 v ulici Na Blatnici. Kumulaci větších kachlových fragmentů obsahoval kruhový objekt se stupňovitě upraveným plochým dnem (k. 507), využívaný nejprve jako sklípek (?), z jehož zásypu byla vyzvednuta torza s heraldickými (orel), tapetovými a rostlinnými motivy. Druhý objekt s keramikou ze 16. a 17. století, do níž byl vhozen i kachel s orlicí, byl původně interpretován jako vydřevená odpadní jímka (k. 533). Nedaleko od obou jam se nacházely dvě kruhová střepiště (k. 509 a 534) napěchovaná zlomky kuchyňské a stolní keramiky včetně defektních kusů. Kromě obou odpadních objektů byl zjištěn i zbytek dřevohlinitého domu a další byl objeven kousek odsud v Hluboké ulici, kde byl v roce 1986 prozkoumán požárem spálený suterén domu z říčních valounů spojovaných jílovou maltou, jehož zánik kladou numismatické nálezy do 20. let 17. století. Kromě středověké a novověké keramiky (nejstarší ze 14. století) se ve vrstvě v úrovni podlahy se zapuštěnou nádobou našlo i několik kruhových obroušených keramických zlomků, které mohly sloužit jako hrnčířské čepele. Další zjištění, které by mohlo osvětlit otázku místní hrnčiřšsé a kachlářské výroby, limituje absence kulturních souvrství, k jejichž kompletnímu odstranění došlo při novodobých terénních úpravách, jak na ploše mezi ulicemi Hluboká a Na Půstkách zdokumentovali pracovníci památkového ústavu při výzkumu v roce 2007 (Boris 1986, 1; Bř́zová 2001, 4; Juchelka 2004, 6-8, 10; 2004a, 156-157; 2006, 233-234; Kolář 2006; 236-237; Müller-Zezula 2014, 57; 2014a, 81; Zezula 2014, 28-29; Holcová 2015, 12-18). 


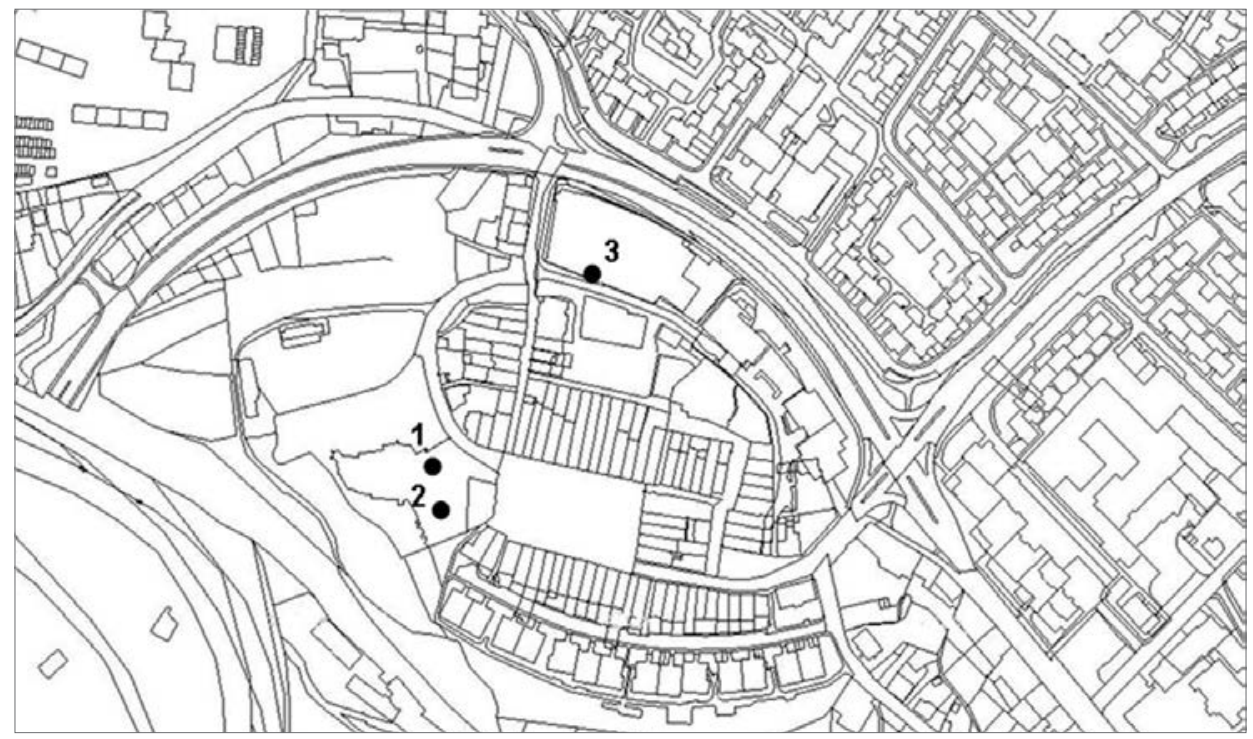

Obr. 5. Frýdek. Poloha nálezů na indikační skice Stabilního katastru z roku 1836.1 - výzkumy na prvním nádvoří zámku v roce 1975; 2 - výzkumy z roku 1995; 3 - výzkum obchodního střediska Kaufland mezi Masarykovou tř́ídou a ulicemi Hlubokou a Na Blatnici v roce 2003.

Abb. 5. Friedek. Lage der Funde auf einer Indikationsskizze des Stabilen Katasters aus dem Jahr 1836. 1 - Grabungen im ersten Schlosshof von 1975; 2 - Grabungen aus dem Jahr 1995; 3 - Grabungen am Einkaufszentrum Kaufland zwischen der Masaryk-Allee und den Straßen Hluboká und Na Blatnici von 2003.

\section{Kachlové soubory ze zámku a města}

Nálezy z hradního př́íkopu zaplněného stavebním odpadem sestávaly z fragmentů pozdně gotických a renesančních komorových kachlů s režným i glazovaným povrchem. Jejich reliéfní výzdobu tvořily motivy ideově čerpající jak ze sakrálních námětů ovlivněných náboženskou symbolikou, tak i profánních, inspirovaných fantaskním světem bájných tvorů, heraldickou symbolikou, portrétním uměním, architekturou nebo floristickou ornamentikou. Všechny tyto námětové okruhy se nevymykaly z běžného výtvarného rámce středoevropské kachlové produkce, avšak do jakých celků a sestav byly v kamnech zakomponovány, to vzhledem k nálezovým okolnostem a torzovitosti dochovaného celku věrohodně zodpovědět nemůžeme. Alespoň rámcově lze některé souvztažnosti vystopovat skrze technologické znaky nebo ikonografický rozbor akceptující formální i obsahová hlediska.

Navzdory tomu, že se jako první tradičně prezentují motivy náboženské, následující řádky se zaměří hlavně na ty exempláře, které se vyskytly v obou souborech a měly identickou výzdobu. Předně jde o téměř kompletně zachovaný čtvercový kachel z výzkumu památkového ústavu (k. 216) s nekorunovanou orlicí v perličkovém rámu (obr. 6:1), který napomohl k přesnější identifikaci heraldického znaku na hrudi podobné orlice s plasticky naznačeným peřím ze zámeckého celku (obr. 6:2), kde tato partie chyběla (Krut’ová 1998, kat. č. 70, tab. XXIV/1; PavlíkVitanovský 2004 397, kat. č. 865; Tymonová 2011, 80, tab. 146/10). Šlo o štítek s tzv. babenberským břevnem, zjištěný dříve na drobném zeleně glazovaném zlomku ze zámeckého konvolutu (obr. 6:3). Sledovaný heraldický znak se v této podobě vyskytl také na zlomku z Holešova, na němž byla zobrazena orlice korunovaná, a také na kachli z hradu Cimburka, na němž byla figura vložena do prvního pole čtvrceného štítu vedle českého lva, slezské orlice a uherských břeven (Vitanovský 2008, 92, 101, kat. č. 297 a 299). Tzv. dělený štítek nesl na hrudi také lev umístěný do prvního pole zemského aliančního znaku na kachli ze Znojma a také další na korunním exempláři z Velkého Meziř́ičí, na němž stylizovaný znak s vodorovným břevnem držel anděl štítonoš (Janál 2001, 91, tab. 3:1; Pavlík 2008, 102, kat. č. 300). Erb, který v tomto provedení 


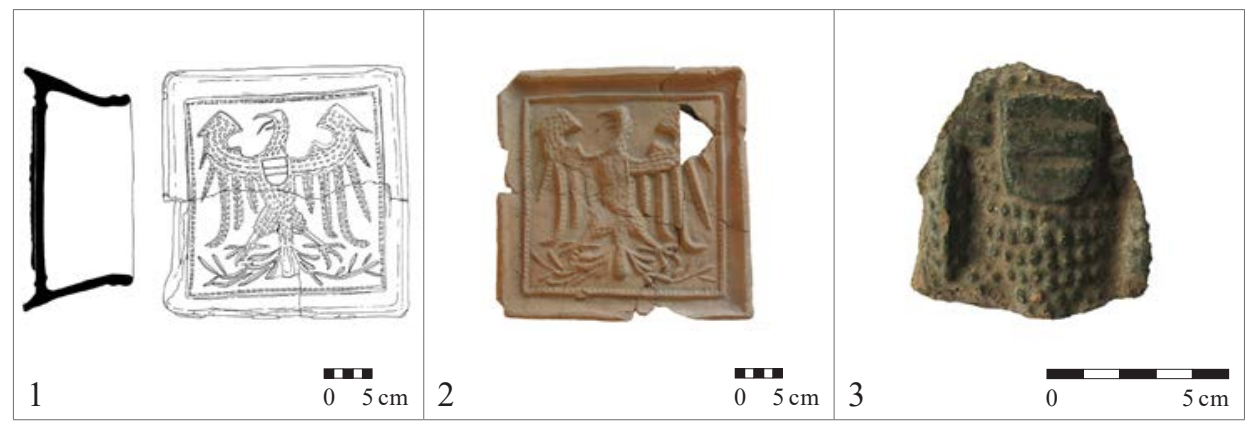

Obr. 6. Frýdek. Motivy kachlů. 1 - orlice (NPÚ ÚOP v Ostravě; podle Juchelka 2004, obr. 1:2); 2 - orlice (Muzeum Beskyd; podle Krut'ová 1998, tab. XXIV); 3 - štítek s babenberským znakem na hrudi orlice (Muzeum Beskyd; foto M. Tymonová). Abb. 6. Friedek. Kachelmotive. 1 - Adler (Nationales Denkmalinstitut Fachstelle in Ostrava; nach Juchelka 2004, Abb. 1:2); 2 - Adler (Beskidenmuseum; nach Krutová 1998, Taf. XXIV); 3 - Schild mit Babenberger Wappen auf der Adlerbrust (Beskidenmuseum; Foto M. Tymonová).

převzali Habsburkové jako dědictví po rakouských Babenbercích, poprvé užil rakouský vévoda Albrecht I. v roce 1282. Jeho souvztažnost s naši zeměmi je manifestována skrze Albrechta I. Habsburského († 1439) a jeho syna Ladislava Pohrobka († 1457), kteří byli př́slušníky panovnické dynastie, jež vládla korunou českých králů (Gall 1977, 125; Hlinomaz 1995, 172; Tymonová 2011, 81; Müller-Zezula 2014, 57). Heraldické datování do první poloviny 15. století však neodpovídá výtvarné podobě kachlového výrobku a z technologického hlediska ani mladšímu typu poměrně nehluboké komory (ca $70 \mathrm{~mm}$ ). Zohledníme-li tato fakta, pak v úvahu přichází doba o století pozdější, tedy období okolo poloviny 16. století, do níž spadají kachle s letopočty 1545 (?) a 1548. Oba uvedené exempláře náležely $\mathrm{k}$ zámeckému celku a byly zastoupeny několika režnými zlomky.

První z těchto časově vročených kusů reprezentuje fragment kamnové korunní římsy v podobě cimbuří s jednou zachovalou stínkou a zešikmenými pultovými stříškami (obr. 7:1-2), jehož alegorický obsah nazačují písemné a číselné znaky umístěné v horních metopovitých segmentech (Krutová 1998, kat. č. 69, tab. XXI; Tymonová 2011, 77, tab. 17/14). V prvním poli zleva to jsou gotická majuskulní písmena „A“ a „O“(,A/NN/O“?) s hvězdou, křížkem a úhelníkem (?) a v sousedním pravém číslice „,“ a „,5“(?), mezi nimiž stojí negativně otočená a vzhưru obrácená „4“ s neidentifikovatelným geometrickým symbolem (úhelník?). Pod nimi se v plochém obdélném poli ČVS nacházel stylizovaný minuskulní nápis, který by mohl znamenat bud' „maius“ s obráceným písmenem „u“ (?), nebo „maria“ (?). Obojí čtení však přesně neodpovídá jednotlivým znakům, a proto i interpretace horního kryptogramu, do něhož mohl být zašifrován letopočet „1545“ (?), není tudíž vůbec jednoznačná. S podobnými obtížemi se potýkala Dana Menoušková, když se snažila rozluštit nápisové texty na římsových kachlích z Nové ulice v Dambořicích („Ama.m/n/“ - „Maria“ (?), „mi:m/us“ aj.), které vyráběli místní hrnčíri od konce 15. století až do př́íchodu habánské komunity v roce 1550 (Menoušková 2003, 183, 203-207, obr. 20, 21, 24). Nábožensky laděné a mnohdy i nesrozumitelné invokační texty byly nejspíše součástí delšího verbálního sdělení, což by mohlo platit i pro nálezy z Frýdku, mezi nimiž se vyskytly i zlomky říms s částečně dochovanými majuskulními nápisy „MARIA“ nebo „JHESUS“, jaké známe z celé řady domácích i zahraničních lokalit (Tymonová 2011, 74-75). Varianty se jménem Panny Marie zpracoval Zdeněk Hazlbauer (1998, 178-180) a nálezy z Opavy s nápisem „IESVS“ publikovala Tereza Krasnokutská, která je považovala za přechodný typ mezi pozdně gotickými a renesančními římsami, což platí i o kachlích s nápisem „Maiu/s/“ z opavského a starojičínského hradu (Krasnokutská 2005, 25-26, tab. 15:1, 2, 63:1; Tymonová 2011, 114, tab. 46, 5-7).

$\mathrm{K}$ přesnější dataci materiálu $\mathrm{z}$ frýdeckého souboru přispěl také režný kachel s letopočtem 1548, jehož dva horní kusy s číselnými znaky se našly na prvním nádvoří, ale v obou výkopech zvlášt' (obr. 7:3). Evidentně jde o kusy z několika různých kachlových jedinců, což stejně jako u jiných podobně rozptýlených zlomků signalizuje jednorázový zásyp hradního příkopu. 
Ústřední motiv v podobě antické vázy, anebo spíše poháru (?) s rostlinným úponkem je umístěn uprostřed čtvercové ČVS s obvodovou vývalkovou lištou, v jejímž levém horním rohu jsou vloženy první dvě číslice letopočtu „1 5 “ $\mathrm{s}$ iniciálou „B“ a na protilehlé pravé straně koncové „4 8“ s negativně obrácenou čtyřkou a iniciálou „H“ (Krut’ová 1998, kat. č. 72, XXVI/1, 2; Tymonová 2011, 84, tab. 48/5). Tento jednoduchý raně renesanční motiv se po výtvarné stránce ještě vyznačuje pozdně gotickým rukopisem, podobně jako je tomu v př́padě jednouché vázy z rožnovského hradu z období kolem roku 1500. Mladší výtvarná provedení z druhé poloviny 16. století jsou již floristicky bohatější a zpravidla mají vázovitou nádobu postavenu pod arkádu, jak to prezentují příklady z hradu v Českých Budějovicích, Národní třídy v Praze nebo z Kouřimi (Brych 2004, 199-200, kat. č. 515, 518; Loskotová 2008, 149-150, kat. č. 484-485).

Pomineme-li okolnost, že se oba kachle vyráběly a v kamnech uživaly po určitou dobu, zaznamenané letopočty $\mathrm{v}$ rozích by mohly mít nejen datační, ale z historického hlediska také událostní význam. V této souvislosti lze připomenout, že v letech 1528-1545 spravoval těšínské knížectví za nedospělého knížete Václava III. Adama Jan z Pernštejna († 1548), který se od roku 1540 stal i Václavovým tchánem. V roce 1545 dosáhl mladý kníže plnoletosti a energicky se ujal samostatné vlády. Okamžitě vyměnil starý úřednický aparát v čele s hejtmanem Janem Sedlickým z Choltic a kancléřem Janem Čelem z Čechovic a ještě téhož roku začal zabavovat majetky mnišských řádů na Těšínsku, což u zkušeného Pernštejna vyvolalo velkou nevoli. Rozdílný prrístup ve věcech správy knížectví a nevyřešené finanční pohledávky brzy přivodily roztržku s bývalým poručníkem, který se mezitím sám dostal do finanční tísně. Po třech letech moravský magnát zemřel, aniž by se dočkal úhrady půjčených peněz, jejichž vrácení začali vymáhat jeho tři pozůstalí synové Jaroslav, Vratislav a Vojtěch (Jež 2007, 74, 78, 80; 2008, 249; 2009a, 2-3; 2009b, 90, 124, 217, 221-223; 2010, 38, 56; Turková 2005, 18, 22). Těžko říct, jestli tyto skutečnosti nějakým způsobem rezonovaly s daty na kachlích, avšak v každém př́ípadě rok Václavova osamostatnění byl důležitým mezníkem v politicko-hospodářském životě těšínského knížectví. Ke konkrétnějšímu výkladu by mohlo přispět rozluštění písmen „ $\mathrm{B}$ “ a „H“ v rozích kachle, v nichž se mohly skrývat iniciály výrobce, čili hrnčiřského mistra, anebo autora předlohy či jiné osoby mající vztah k nějaké významné události. Za stávajícího poznání však tyto souvislosti nedovedeme identifikovat.

Náboženské zaměření a sympatie knížete Václava Adama k protestantskému hnutí indikovala přítomnost několika zlomků s motivy z cyklu dvanácti starozákonních hrdinů ztvárněných podle Penczových ilustrací v díle Hanse Sachse (Die Erenport der zwelff Sieghafften Helden des alten Testaments und ander Thyrannen), které byly publikovány v roce 1531 (Žegklitz 2012, 271; 2012a, 33; Majewski 2015, 132). Ve Frýdku se z této kachlové série rozšířené od Švýcarska až do Pobaltí vyskytlo několik zlomků se segmentovými sloupy a vyobrazením Gedeona, jehož identická verze byla zjištěna na hradech v Bruntále a Slezské Ostravě (Tymonová 2012, 680, 682-683, obr. 1:3-12, 2:1; Majewski 2015, 132-133, 149-151). Stejný Gedeon se v bruntálském konvolutu vyskytl ve spojení se zlomky nesoucími zbytky oblouků, zdobenými spletenými listy granátovníku, jaké jsou charakteristické pro výrobky z dílny Hanse Bermana (Tymonová 2011, 33, tab. 1/15-16, tab. 2/3-6). Dokladem toho, že v této dílně vznikaly i kachle s motivy starozákonního hrdinského cyklu, je kachel s Amaziášem nalezený v polském Stargardu s charakteristickými segmentovými sloupy a iniciálou „H“ před částečně dochovaným letopočtem „1 5“v dolní partii kachle. I když se na bruntálských kachlích Bermanovo jméno neobjevilo, není vyloučeno, že tento výtvarně i materiálově homogenní celek reprezentoval domácí výrobky ovlivněné touto dílnou, protože hrnčíři z originální matrice mohli samostatně použít pouze orámování nebo hlavní reliéf. Jak ukazují př́iklady z Dánska, Meklenburska a polského Západního Pomoří, výrobci kombinováním různých motivů výšku kachle zkracovali, a proto Bermanovu signaturu umístěnou vespod reliéfu někdy vypustili či zamazali (Kamiński 2011, 310; Majewski 2015, 151-152, Ryc. V25). Exempláře s tímto v podstatě neměnným typem arkády, jež u nás známe hlavně ze severovýchodních Čech, by naznačovaly průnik také do českého Slezska, kde protestantismus nalezl konfesně příznivé prostředí (Soukup-Soukupová-Šrejbr 2012). Ve Frýdku šíření nekatolické konfese souviselo s náboženským smýšlením Václava III. Adama, který se 
někdy po roce 1555 přiklonil k Lutherovu učení a začal vystupovat jako aktivní propagátor evangelického náboženství. Stalo se tak ještě před uzavřením zásnubní smlouvy s druhou manželkou, saskou kněžnou Sidonii Kateřinou, potvrzené v roce 1567 v saském městě Geyeru za účasti kurfiřta Augusta a lehnického knížete Jindřicha IX. (Jež 2009b, 155; 2010, 58; 2012a, 134-135).

Reformační vliv na frýdeckém materiálu prozrazují i jiné kachle z druhé poloviny 16 . století, jako kupř́íkladu vyobrazení muže čtoucího knihu (obr. 7:4) ztotožňovaného s vůdcem německé reformace Martinem Lutherem, jehož kachlová obdoba pochází z neznámé lokality na východním Slovensku. Kazetově uspořádané pásy s geometrickými a rostlinnými vzory po bocích arkád měly i nálezy z radnice v Bytomi s portréty ztotožňovanými s Annou Uherskou, Ferdinandem I. a Sulejmanem Nádherným, jejichž vznik je kladen do doby po roce 1526 (Menoušková 2008, 75, 82, kat. č. 238; Tymonová 2011, 78, tab. 48/19-20; Egyházy-Jurovská-Füryová 1993, obr. 42; Andrzejewska 2010, 106-111, 119, Ryc. 4-5, 6). K protestantským motivům lze přiřadit i zeleně glazovaný kousek s manželkou Kristiána II. Izabelou Habsburskou s nápisem „DENEMAR“, který je totožný s kachlem z Náchoda (Pavlík-Vitanovský 2004, 114, 257, kat. č. 723; Menoušková 2008, 74-75, 80, kat. č. 232). Portrét dánské královny doplňuje částečně zachovaný saský znak na archivoltě, který drží heraldicky vlevo gryf a vpravo lev, jenž se ovšem nezachoval (obr. 7:5). Toto charakteristické orámování používané od poloviny 16. století na kachlích s portréty saských knížat dokládá originální matrice s postavou knížete Kristiána II. nalezená v saské Grimě nebo úlomky pozitivů se lvem a gryfem z Pekařské ulice v Opavě. Od přelomu 17. věku se pod arkádou objevují převážně habsburští katoličtí panovníci, což souviselo se změnou náboženských poměrů, v jejichž důsledku reformační témata z kachlové tvorby mizí (Pavlík-Vitanovský 2004, 114, 257, kat. č. 723; Krasnokutská 2005, 52, tab. 53:1, 2; Majewski 2015, 196). Na frýdeckém panství

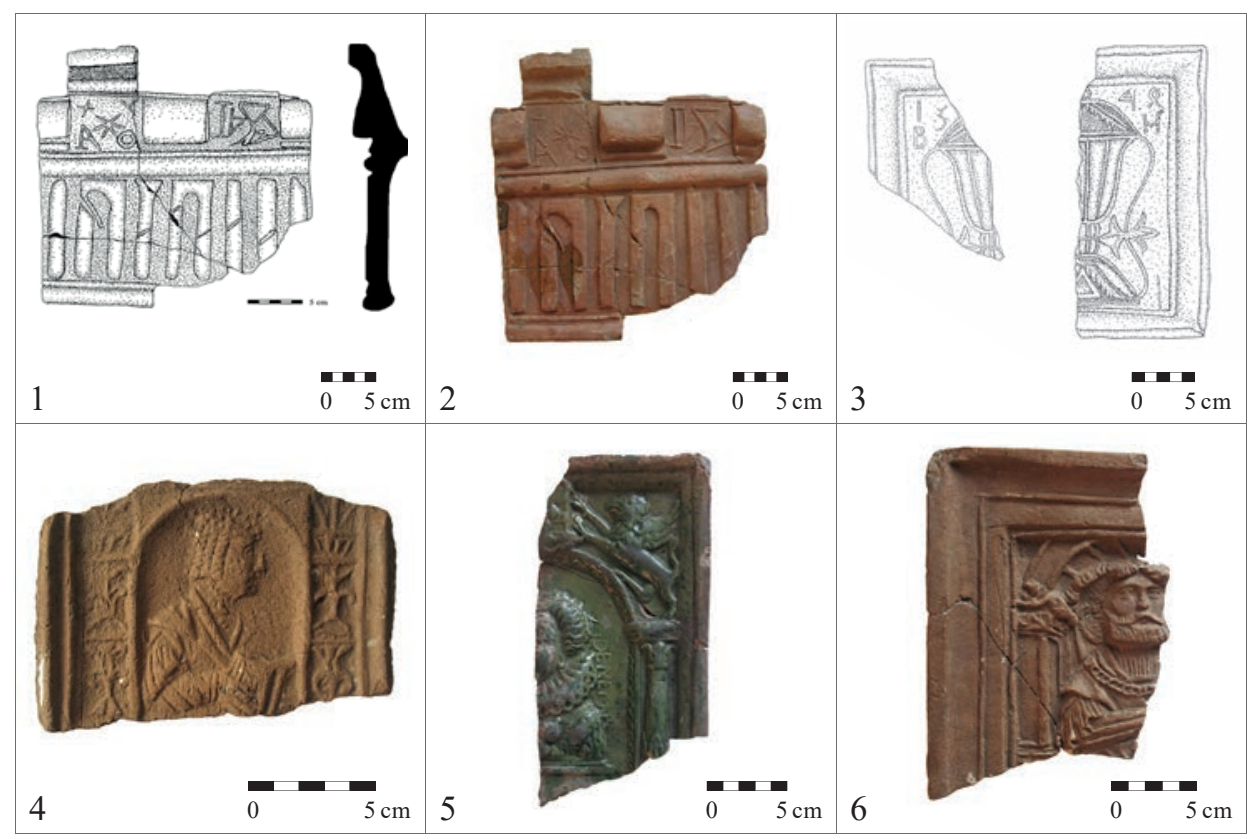

Obr. 7. Frýdek. Motivy kachlů. 1, 2 - římsový kachel s letopočtem 1545 (?) (Muzeum Beskyd; podle Krut'ová 1998, tab. XXI; foto M. Tymonová); 3 - řádkový kachel s letopočtem 1548 (Muzeum Beskyd; římsový kachel s letopočtem 1545; podle Krut'ová 1998, tab. XXVI, 1-2); 4 - muž s knihou, snad Martin Luther? (Muzeum Beskyd; foto M. Tymonová); 5 - portrét Izabely Habsburské s nápisem „DENEMAR“ (Muzeum Beskyd, foto M. Tymonová); 6 - muž s plnovousem (Muzeum Beskyd, foto M. Tymonová). Abb. 7. Friedek. Kachelmotive. 1, 2 - Simskachel mit Jahreszahl 1545 (?) (Beskidenmuseum; nach Krut'ová 1998, Taf. XXI; Foto M. Tymonová); 3 - Füllkachel mit Jahreszahl 1548 (Beskidenmuseum; Simskachel mit Jahreszahl 1545; nach Krut'ová 1998, Taf. XXVI, 1-2); 4 - Mann mit Buch, vielleicht Martin Luther? (Beskidenmuseum; Foto M. Tymonová); 5 - Porträt von Isabelle von Habsburg mit Inschrift „DENEMAR“ (Beskidenmuseum, Foto M. Tymonová); 6 - Mann mit Vollbart (Beskidenmuseum, Foto M. Tymonová). 
rekatolizační kurz tvrdě prosazoval olomoucký biskup Stanislav Pavlovský a po něm i Bruntálští z Vrbna (Jež 2014a, 78-79). Jen velice volně by s protestantským prostředím mohl souviset režný zlomek kachle s kazetovou archivoltou, vyskytující se na reformačních kachlích, pod níž se nachází urozený muž s plnovousem (obr. 7:6), jehož obdoba se našla v Kolářské ulici v Opavě (Krasnokutská 2005, 22, tab. 8:1-3, 62:1; Menoušková 2008, 76, 86, kat. č. 258).

Vedle kachlů s náboženskou tematikou by do staršího horizontu zámeckých nálezů z první poloviny 16. století mohl náležet ještě mnohokrát zmiňovaný gryf kráčející heraldicky vlevo (obr. 8:1), dochovaný na režných i zeleně glazovaných zlomcích, který má místo sukovatkového rámu věnec s hroznovitými šišticemi (Menoušková 2008a, 39, 47, kat. č. 117; Tymonová 2009, 189-190, tab. 2/4; 2011, tab. 48, 11-13). Z žánrových námětů by do okruhu raně renesančních motivů náležel také lancknecht oděný v kabátci s prostřihávanými rukávy s halapartnou v ruce a krátkým mečem u pasu (obr. 8:2), jehož nejbližší analogie se našla ve Starém Bohumíně (Břízová 1996, 12-13, tab. 15; Krutová 1998, kat. č. 45, tab. XXII; Loskotová 2008, 57, 64, kat. č. 179-182; Kováčik-Veselá 2009, 293-293, Fig. 5-6; Tymonová 2011, 77, tab. 51/6-7). Spadat by sem mohl i kachel s rozetou s podobným orámováním v podobě pásu hroznů s vějířvitými aplikacemi v rozích, jako měl gryf (obr. 8:3), jehož fragmenty se našly ve výkopu před vstupem do zámku i v sondě uprostřed nádvoří (Loskotová 2008, 140, 145, kat. č. 458; 2009, 195-196, tab. 4/7; 2014, 82, tab. 47/8, 51/4). Kromě tohoto exempláře obsahoval zámecký konvolut ještě další varianty rozet s různě kombinovanými okvětními lístky, jejichž četné modifikace náleží k nejrozšířenějším renesančním motivům s centrálně uspořádanými vegetabilními prvky.

Florální i architektonické vzory se hojně vyskytovaly i ve výzdobě římsových kachlů zasazovaných do korunních partií kamen, v nichž ještě vedle balustrů a palmet přežívala stará gotická cimbuří (obr. 8:4-6). Do série architekturou inspirovaných ornamentů spadají ještě klasická čtvercová i obdélná zrcadla se zahloubenou prázdnou nebo zdobenou středovou plochou

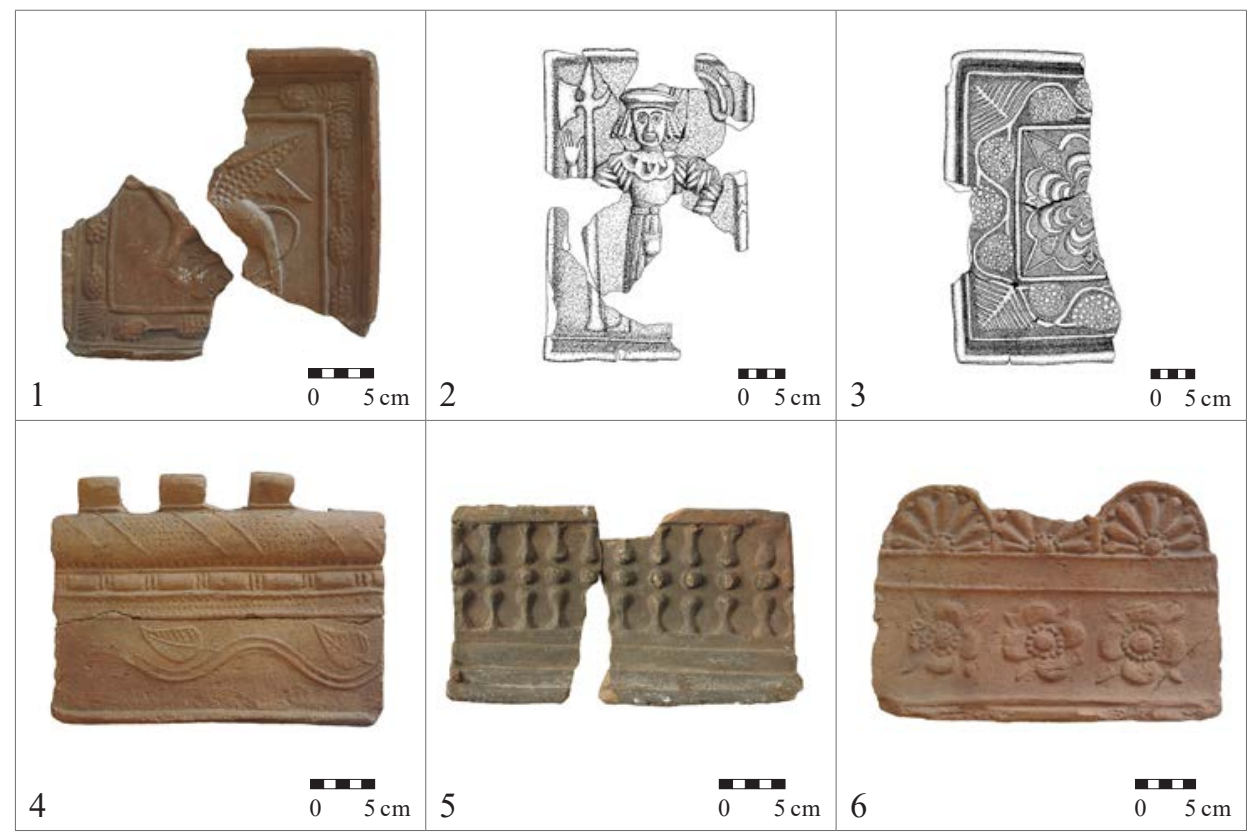

Obr. 8. Frýdek. Motivy kachlů. 1 - gryf (Muzeum Beskyd; foto M. Tymonová); 2 - lancknecht (Muzeum Beskyd; podle Krut'ová 1998, tab. XXII); 3 - rozeta (Muzeum Beskyd; podle Krut'ová 1998, tab. VIII); 4-6 - římsové kachle (Muzeum Beskyd, foto M. Tymonová).

Abb. 8. Friedek. Kachelmotive. 1 - Greif (Beskidenmuseum; Foto M. Tymonová); 2 - Landsknecht (Beskidenmuseum; nach Krut'ová 1998, Taf. XXII); 3 - Rosette (Beskidenmuseum; nach Krut’ová 1998, Taf. VIII); 4-6 - Simskachel (Beskidenmuseum, Foto M. Tymonová). 
vyplněnou plasticky ztvárněnou mřížkou či hvězdou (obr. 9:1-4). Různě provedené mřižky se vyskytly na kachlích z východopolského zámku v Inowłodzi, které jsou datovány do rozmezí let 1521-1526 (Motylewska 2008, 68, 122, Tabl. XXXVI, 1-3). Rostlinné prvky na středovém zrcadle byly hojně zaregistrovány také v Opavě, kde se vyskytly i exempláře s hladkými nezdobenými plochami (Pekařská nebo Ostrožná ulice); další pochází z Opolí nebo Západního Pomoří a mnoha dalších lokalit (Dymek 1995, 269, Tabl. XXXII; Břízová 1996, 11, tab. 11, 12; Krut'ová 1998, č. 33, 35; tab. XII-1, XIII-1; Krasnokutská 2005, 66; Tymonová 2011, 85, tab. 48/8-10; Majewski 2015, 219, Ryc. V.88). Zatím však není jasné, zda kachle se zdobenými zrcadly můžeme považovat za apriori starší, protože některé hladké tvary ještě disponují archaickou poloválcovou komorou, typickou pro pozdně gotické zboží. V polovině 16. století se paralelně objevují také kachle s centrálními zahloubenými i vypouklými medailony doplněné hvězdicovitými nebo listovými ornamenty (obr. 9:5, 6), o nichž bylo pojednáno v minulém čísle tohoto sborníku v souvislosti s materiálem z Javorníka (Tymonová 2015).

Další kachle, které byly zastoupeny v zámeckém i městském souboru, nesly reliéf dvouhlavého císařského korunovaného orla s nimby kolem hlav, mečem v pravém a jablkem v levém pařátu. Figuru doplňovaly jednoduché pěticípé hvězdy umístěné v rozích. Tento institucionální říšský znak se v kachlové tvorbě v této podobě objevil v 16. století, i když v heraldických souvislostech se používal již dříve (Tymonová 2011, 81, tab. 51/1; Müller-Zezula 2014a, 81). Režný fragment se zbytkem rámové komory hluboké 65 mm vytažený v roce 1975 z hradního př́ikopu se dochoval pouze z poloviny (obr. 10:1), ale jemu identický zeleně glazovaný exemplář vytažený z odpadní jámy na severní straně města byl téměř celý (obr. 10:2). Jeho analogie z Opavy, Czechowic, Opole a dalších míst umožňují vročení do druhé poloviny 16. až počátku 17. století (Dymek 1995, 35). Podobně byly datovány i ostatní kachle s habánskými tapetovými vzory ze zásypu odpadní jámy, které mají původ v produkci zaalpské oblasti jižního Německa a Švýcarska.

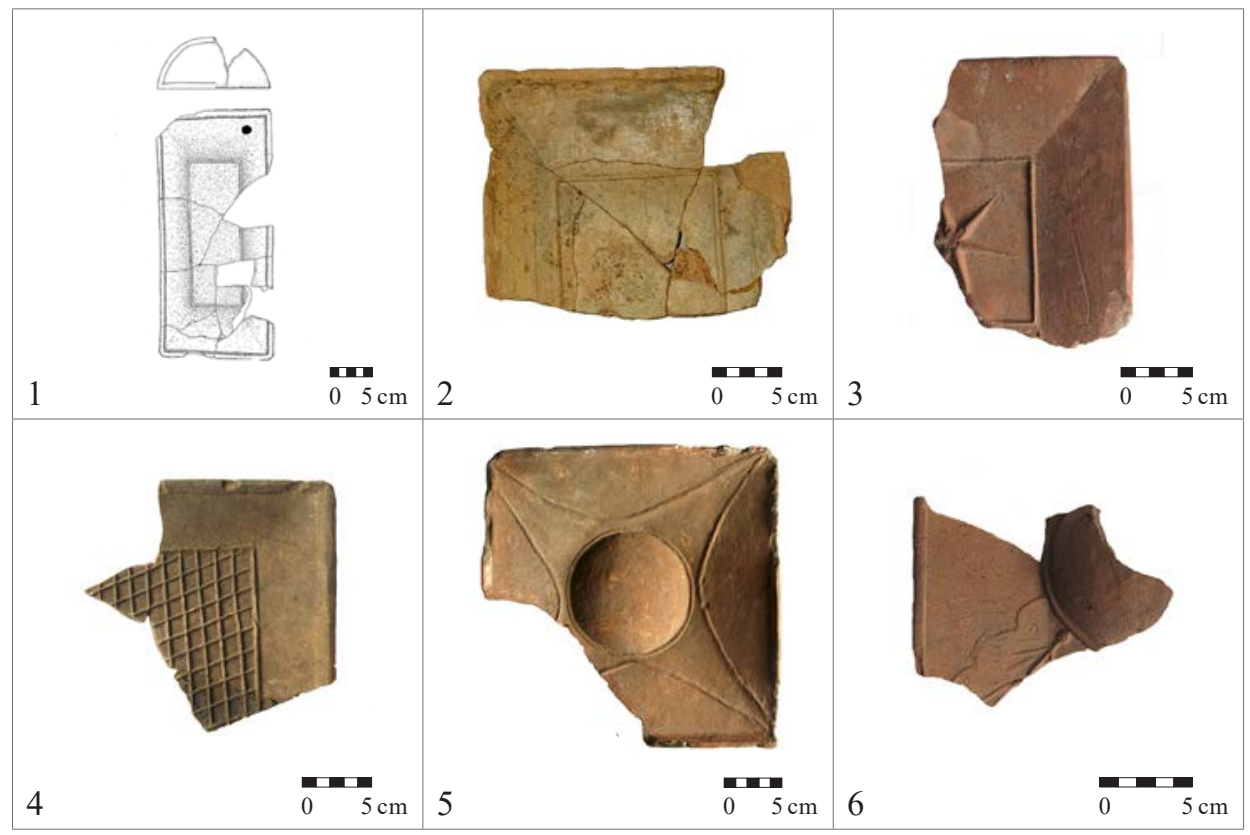

Obr. 9. Frýdek. Motivy kachlů. 1 - zrcadlový kachel s poloválcovou komorou (Muzeum Beskyd; podle Krut'ová 1998, tab. XI); 2-4 - zrcadlové kachle (Muzeum Beskyd; foto M. Tymonová); 5-6 - medailonové kachle (Muzeum Beskyd; foto M. Tymonová).

Abb. 9. Friedek. Kachelmotive. 1 - Spiegelkachel mit halbzylinderförmigem Hals (Beskidenmuseum; nach Krut’ová 1998, Taf. XI); 2-4 - Spiegelkachel (Beskidenmuseum; Foto M. Tymonová); 5-6 - Medaillonkachel (Beskidenmuseum; Foto M. Tymonová). 
K tapetovým vzorům sestavovaným do nekonečných mozaikových koberců náleží kompletně zachovalý kachel se srdéčkovým páskovým vzorem a vinnými hrozny uspořádanými kolem drobné středové rozetky. Ve Frýdku byl jeden exemplář vytažen z jámy spolu s výše zmíněným kachlem s císařským orlem (obr. 10:3) a druhý ze zámeckého př́íkopu (obr. 10:4). Analogie k těmto srdéčkovým kombinacím pochází z hradu Buchlova, Strážnice, Nového Strašecí, slovenského Děvína, Bratislavy či polského Stargardu (Holčík 1976, obr. 26; Pajer 1983, 114, obr. 56; Gyurica 1992, 27-28, XIX; Pavlík-Vitanovský 2004, 180, 309, 435, kat. č. 1265-1267; Divileková 2008, 196, obr. 11; Loskotová 2009, 19, obr. 12; Holub-Jordánková-Loskotová 2009, 276, 278, Fig. 10; Tymonová 2011, 87, tab. 46/3; Majewski 2015, 216, Ryc. V 84/9). Z téže odpadní jámy pochází ještě kachle s arabeskovými motivy, které se na přelomu 16. a 17. století transformovaly z akantů a palmet (obr. 10:5, 6). Používání kombinace podobných rostlinných a geometrických ornamentů pokrývajících celou plochu kamen dosáhlo svého vrcholu na počátku 17. věku.

Tapetové ornamenty pronikaly do naší kachlové výroby prostřednictvím originálních habánských výrobků, které od poloviny 16. století začali napodobovat domácí hrnčíři, jak to dokazuje nález matrice z Truhlářské ulice v Praze s letopočtem 1554 (Žegklitz-Vitanovský-Zavřel 2009, 432, 434, 450, obr. 8; Tymonová 2015, 949). Jejich typologií se nedávno zabývala Irena Loskotová, která na základě rozboru materiálu z Brna - Panské ulice 6-8 vyčlenila sedm výzdobných variant datovaných do let 1607-1617. Až na jeden originální habánský výrobek s kružnicovým vzorem, analogický nálezům ze Strážnice, představovaly všechny typy napodobeniny vzniklé kopírováním habánských předloh (Pajer 1983, 112; Holub-Jordánková-Loskotová 2009, 3). Domácí výrobky po technologické stránce nedosahovaly tak vysoké kvality jako originály a vyznačovaly se mírně odlišnými modifikacemi rostlinných prvků, které charakterizovalo určité zhrubnutí.

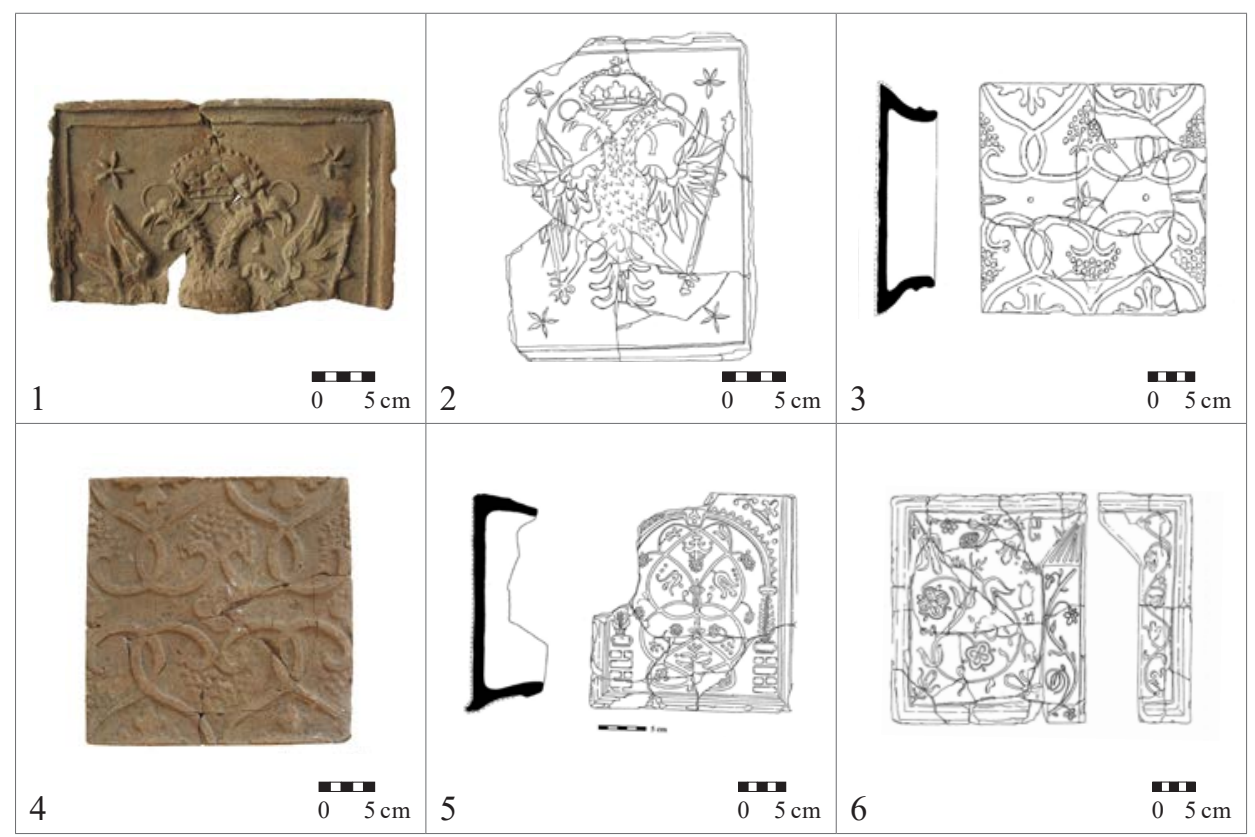

Obr. 10. Frýdek. Motivy kachlů. 1 - polovina kachle s říšským orlem (Muzeum Beskyd; foto M. Tymonová); 2 - kachel s říšským orlem (NPÚ ÚOP v Ostravě; podle Juchelka 2004, obr. 5); 3 - kachel se srdéčkovým vzorem (NPÚ ÚOP v Ostravě; podle Juchelka 2004, obr. 1:1); 4 - kachel se srdéčkovým vzorem (Muzeum Beskyd; foto M. Tymonová); 5-6 - řádkový a rohový kachel s vegetabilní výzdobou (NPÚ ÚOP v Ostravě; podle Juchelka 2004, obr. 2-3).

Abb. 10. Friedek. Kachelmotive. 1 - Kachelhälfte mit Reichsadler (Beskidenmuseum; Foto M. Tymonová); 2 - Kachel mit Reichsadler (Nationales Denkmalinstitut Fachstelle in Ostrava; nach Juchelka 2004, Abb. 5); 3 - Kachel mit herzförmigem Muster (Nationales Denkmalinstitut Fachstelle in Ostrava; nach Juchelka 2004, Abb. 1:1); 4 - Kachel mit herzförmigem Muster (Beskidenmuseum; Foto M. Tymonová); 5-6 - Füll- und Eckkachel mit vegetabiler Verzierung (Nationales Denkmalinstitut Fachstelle in Ostrava; nach Juchelka 2004, Abb. 2-3). 
V zámeckém konvolutu byly nejčetněji zastoupeny kachle s kružnicovými vzory kombinované se štípatkami a listovcem (obr. 11:1) nebo hvězdami (obr. 11:2), které se dochovaly i v nárožní variantě (obr. 11:3). Podobné nálezy s kruhovými výsečemi byly zjištěny v Opavě v souborech z Masarykovy, Mnišské a Krnovské ulice (Pajer 1983, 42, 112, obr. 51-54; Pavlík-Vitanovský 2004, 309, 435, kat. č. 1258-1259; Krasnokutská 2005, 33, 35, 40, obr. 29:11, 37:1, 2, 28, 2:4; Loskotová 2009, 19; 2009a, 275-276, Fig. 3). Zahraniční analogie z počátku 17. století reprezentují nálezy ze Slovenska nebo Mad’arska (Bratislava, Lubovňa, Sárospatak, Füzér, Pácin), kam se novokřtěnci uchýlili po vypovězení v roce 1622 (Gyurica 1992, 28, 115, 154, XVII-XVIII rajz.; Feld-Chovanec-Dankó-Tamási 1996, 46; Uličný 2005, 243-244). Nálezů existuje podstatně více, ale ne vždy byly kvůli četnosti a ikonografické jednotvárnosti publikovány.

Dalši tapetový typ zastupuje kompletně zachovalý režný kus s tzv. přibíjeným páskovým ornamentem (obr. 11:4) a lilií uprostřed mandorlového pole, kterou doplňují lipové květy. Výška rámové komory se podobně jako u ostatních kachlů tohoto typu pohybuje okolo 6-7 centimetrů (Krutová 1998, kat. č. 3, tab. III/1; Pavlík-Vitanovský 2004, 180, 309, 434, kat. č. 1263; Loskotová 2008, 141, 151, kat. č. 491; Holub-Jordánková-Loskotová 2009, 276, 279, Fig. 13). K domácím produktům vyráběným podle habánských předloh náležely také kachle s oválovým ornamentem, jehož mandorlová pole vyplňovaly protáhlé liliovité palmety (obr. 11:5, 6), které se dochovaly v řádkovém i rohovém provedení (Krutová 1998, kat. č. 2, tab. II/1; Tymonová 2011, 88, tab. 49/10, 50/10). Kromě geometrických a vegetabilních prvků se v tapetových provedeních vyskytl i císařský orel, známý pouze ze sádrového odlitku (obr. 11:7). Ve druhé polovině 16. století byly oblíbené kachle s kruhovými páskovými medailony vyplněné stylizovaným rostlinstvem (obr. 8,9). Dalších ornamentů se na kachlích z Frýdku vyskytlo více, avšak jejich identifikaci v př́padě zámeckého materiálu komplikuje pouze základně provedená kompletace, která neumožňuje zjištění konkrétního počtu jedinců toho kterého motivu.

\section{Závěr}

Kachle z frýdeckého zámku a prostoru při severním okraji historického jádra města představují cenný soubor, jehož datování se rámcově kryje se stavebními úpravami původně zeměpanského a od roku 1573 šlechtického sídla. Nejstarší exempláře spadají do období kolem roku 1500 či první třetiny 16. století, kdy hrad nechal zmodernizovat těšínský kníže Kazimír II., který frýdecko-místecké panství př́mo spravoval v letech 1474-1480 a 1492-1528. Kachle z pozdně gotických kamen datují kachle s gryfem a časně renesanční, z první poloviny 16. století, exempláře s letopočty. Jejich vznik souvisel s poručnickou vládou Pernštejnů za knížete Václava III. Adama, který inklinoval k reformačním myšlenkám, což je možné vysledovat i v ikonografii kachlového materiálu.

Ve druhé polovině 16. století, kdy kachlová kamna pronikla i do měštanských interiérů, se v kachlové produkci prosadily tapetové a arabeskové vzory spolu s heraldickou symbolikou reprezentovanou kachlem s orlicí z parcel pod zámeckým náměstím, kde se dříve nacházely domy vrchnostenských úředníků dohlížejících na správu panství. Jedním z nich byl i Linhart Kaše, jemuž v roce 1545 daroval mladý kníže dům osvobozený od poplatků, který stál „(...) na mistě našem svobodném k zámku Frýdku náležitým, kterýž přileži niže zámku u zdi městské a proti láz-

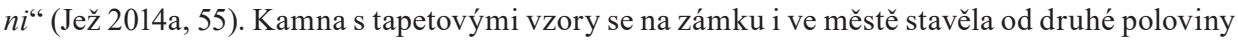
16. století do prvních desetiletí století následujícího, kdy Frýdek vlastnili Bruntálští z Vrbna a po nich Oppersdorfové. Výskyt shodných jedinců v obou souborech dokládá, že podobná kamna jako na zámku si mohli dovolit i př́íslušníci úřednické a měšt’anské elity, a zároveň, že i v aristokratickém zámeckém prostředí se stavěla kamnová tělesa v dražším glazovaném i v levnějším režném provedení.

Kachle nalezené ve Frýdku mohly vzniknout v hrnčiřské dílně u městské zdi pod zámkem, ale jisté to není, protože spolehlivě byly zatím doloženy pouze stopy hrnčířské činnosti a likvidace kachlového odpadu z funkčních kamnových těles. Nálezy jsou však o to cennější, že se zachovaly navzdory rozsáhlým novověkým úpravám, při nichž došlo k odstranění značné části kulturních souvrství až na geologické podloží. 


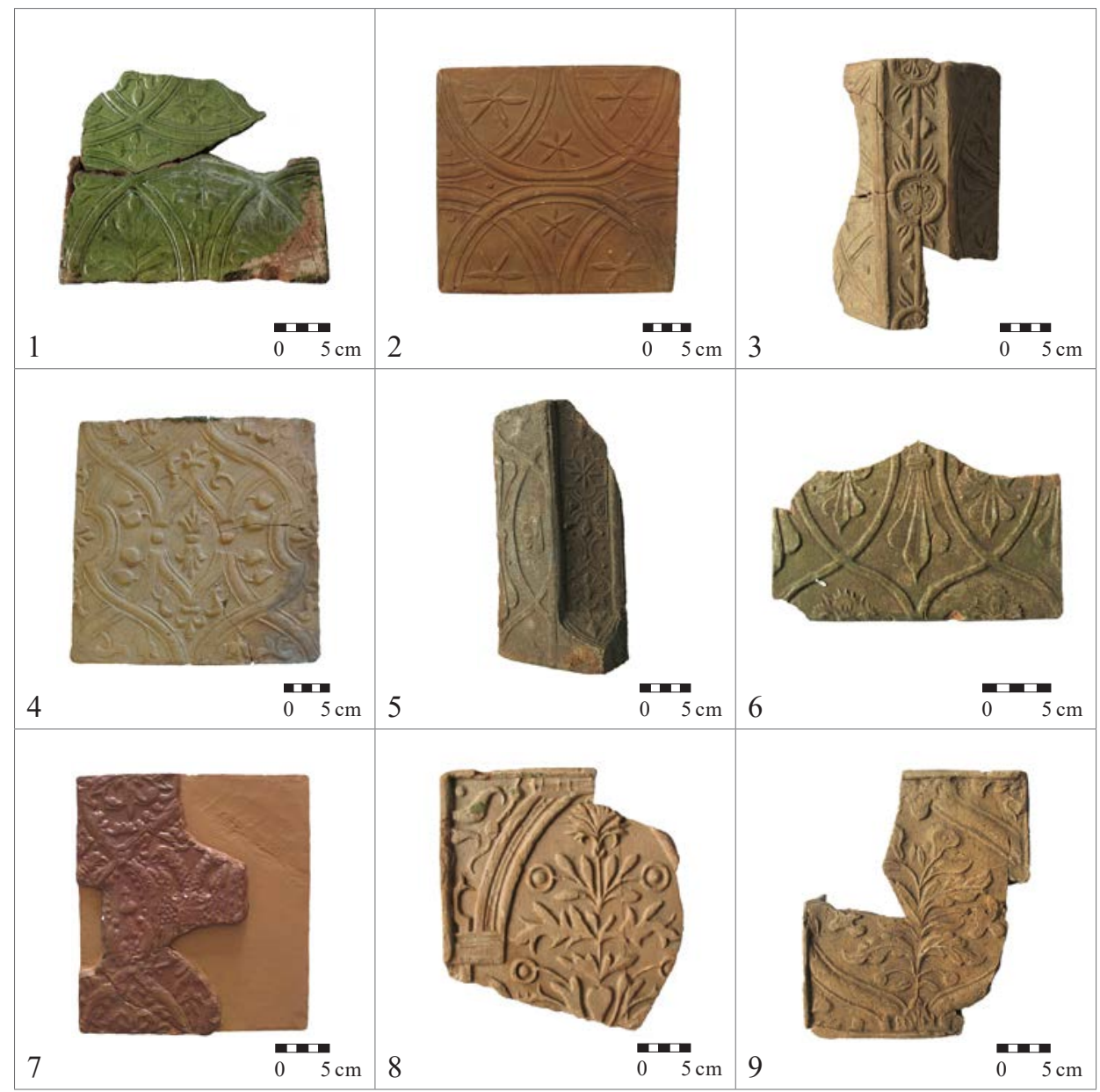

Obr. 11. Frýdek. Motivy kachlů. 1-2 - kachle s kružnicovým vzorem (Muzeum Beskyd; foto M. Tymonová); 3 - rohový kachel s kružnicovým vzorem (Muzeum Beskyd; foto M. Tymonová); 4-5- řádkový a rohový kachel s tzv. přibíjeným vzorem (Muzeum Beskyd; foto M. Tymonová); 6 - kachel s oválovým vzorem (Muzeum Beskyd, foto M. Tymonová); 7 - sádrová kopie kachle s císařským orlem (Muzeum Beskyd, foto M. Tymonová); 8-9- kachle s vegetabilní výzdobou v páskových medailonech (Muzeum Beskyd; foto M. Tymonová).

Abb. 11. Friedek. Kachelmotive. 1-2 - Kachel mit kreisförmigem Muster (Beskidenmuseum; Foto M. Tymonová); 3 - Eckkachel mit kreisförmigem Muster (Beskidenmuseum; Foto M. Tymonová); 4-5 - Füll- und Eckkachel mit sog. angeschlagenem Muster (Beskidenmuseum; Foto M. Tymonová); 6 - Kachel mit ovalem Muster (Beskidenmuseum, Foto M. Tymonová); 7 - Gipskopie einer Kachel mit Kaiseradler (Beskidenmuseum, Foto M. Tymonová); 8-9 - Kacheln mit vegetabiler Verzierung in Bandmedaillons (Beskidenmuseum; Foto M. Tymonová).

\section{Literatura}

ANDRZEJEWSKA, A., 2010: Zespół kafli renesansowych z ratusza w Bytomiu - A collection of Tiles from the town hall in Bytom, Acta Universitatis Lodziensis. Folia Archaeologica 27, 101-119.

A1 SAHEB, J., 2004: Ǩeka Ostravice a její role v dějinách Frýdlantu nad Ostravicí. In: Sborník Státního okresního archivu ve Frýdku-Místku 5, 79-96. Frýdek-Místek.

- 2014: Počátky a rozvoj Místku do roku 1434. In: Frýdek-Místek. Historie - Kultura - Lidé (Adamec, T. a kol., edd.), 42-47. Praha.

AL SAHEB, J.-PINDUR, D., 2005: Příspěvek k dějinám frýdeckého panství v 17. století, Vlastivědné listy 31, č. $1,4-10$. 
-2008: Nejstarší dějiny farního kostela sv. Jana Křtitele ve Frýdku. In: Těšínský muzejní sborník 3, $176-191$. Český Těšín.

BAKALA, J., 1971: Komentář k bádání o počátcích města Frýdku, ČSM B XX, 111-130.

- 1982: Osídlení Frýdecka a Jablunkovska v období vrcholného feudalismu. Frýdek-Místek.

- 2005: 700 let Ujazdského rejstř́iku, Těšínsko 48, č. 4, 14-16.

BORIS, M., 1981: O počátcích města Frýdku-Místku, Pobeskydí, Společenské vědy 2, 4-19.

BORIS, M.-ŽÁČEK, R., 1981: Frýdek-Místek. Frýdek - zámek, místnost č. 17. Rkp. nálezové zprávy č. 995 ulož. v archivu Muzea Beskyd Frýdek-Místek.

BRYCH, V., 2004: Kachle doby gotické, renesanční a raně barokní. Výběrový katalog Národního muzea v Praze. Praha.

BŘÍZOVÁ, Z., 1996: Frýdek-Místek, zámek - 1. nádvoří: Nálezová zpráva. Frýdek-Místek. Rkp. nálezové zprávy č. 2359 ulož. v archivu v Muzea Beskyd Frýdek-Místek.

- 2001: Sanace hradební zdi ve Frýdku. Rkp. nálezové zprávy č. 2478 ulož. v archivu Muzea Beskyd Frýdek-Místek.

ČAPSKÝ, M., 2011: Hospodářský obraz moravsko-slezského pomezí v době vlády Jana Lucemburského. In: Král, který létal. Moravsko-slezské pomezí v kontextu středoevropského prostoru doby Jana Lucemburského, 39-50. Ostrava.

GALL, F., 1977: Österreichische Wappenkunde. Wien - Köln.

DIVILEKOVÁ, D., 2008: Vykurovanie na hrade Devín - Wie auf der Burg Devín (Theben) geheizt wurde, AH 33, 185-198.

DYMEK, K., 1995: Średniowieczne i renesansowe kafle śłąskie. Wrocław.

GYURICZA, A., 1992: Reneszánsz Északkelet-Magyarországról. Miskolcz.

EGYHÁZY-JUROVSKÁ, B.-FÜRYOVÁ, K., 1993: Stredoveké kachlice. Katalog výstavy ve Slovenském Národním muzeu. Bratislava.

FELD, I.-CHOVANEC, J.-DANKÓ, J. K.-TAMÁSI, E., 1996: A Gótikától a Habánokig. Kályhacsempék Abaúj, Sáros és Zemplén vármegyékből. A sárospataki Rákóczi Múzeum Füzetei 31. Sárospatak.

HAZLBAUER, Z., 1998: Krása středověkých kamen. Odkaz náboženských idejí v českém uměleckém řemesle. Praha.

HLINOMAZ, M., 1995: Ke státní a zemské symbolice českého státu v období 1526-1918, Paginae historie. Sborník Státního ústředního archivu v Praze 3, 152-194.

HOLCOVÁ, D., 2015: Nálezy středověké a novověké keramiky z Frýdku-Místku - Findings of the medieval and modern pottery from Frydek-Mistek, rkp. nepubl. bakalářské práce na FPF Slezské univerzity v Opavě, ved. práce PhDr. V. Goš, CSc.

HOLČÍK, Š., 1976: Stredoveké kachlice na Slovensku, ZbSNM 70, História, 70, 91-112.

HOLUB, P.-JORDÁNKOVÁ, H.-LOSKOTOVÁ, I., 2009: Early Modern period Brno stove tiles with a mosaic (tapestry) pattern. In: Studies in Post-medieval Archaeology 3. Post-medieval ceramics. Production, assortment, usage - Novověká keramika. Výroba, sortiment, užití - Neuzeitliche Keramik. Produktion, Sortiment, Verwendung, 273-302. Prague.

JANÁL, J., 2001: Komorové kachle ve sbírkách holešovského muzea, Archeologie Moravy a Slezska, 90-97.

JANIŠOVÁ, J., 2014: Heraldická výzdoba Moravského zemského zřízení z roku 1604 (k ikonografii zasedání zemského soudu) - Heraldic embellishment of the Moravian land ordinance from 1604 (As to the iconography of the provincial court session), Acta historica Universitatis Silesianae Opaviensis 7, 49-74.

JEŽ, R., 2007: Těšínští Piastovci a jejich vztahy s Pernštejny v 16. století (S edicí korespondence z let 1554-1581), rkp. nepubl. magisterské diplomové práce na MU, Brno, ved. práce doc. PhDr. Mgr. Tomáš Knoz, Ph.D.

- 2008: Správa Těšínského knížectví Janem z Pernštejna v letech 1528-1545, Práce a studie Muzea Beskyd - společenské vědy 20, 225-267.

- 2008a: Manželské soužití knížete Václava III. Adama s Marií z Pernštejna v polovině 16. století, Těšínsko 51 , č. $4,1-15$.

- 2009: „...oznámili sú, jakž Bartka Šestáka zabili...“K dějinám městského trestního práva na Těšínsku v raném novověku. In: Sborník Státního okresního archivu ve Frýdku-Místku 10, 9-34. Frýdek-Místek.

- 2009a: Slavnosti na dvorech těšínských knížat renesančního věku - Festivities in courts of Těšín princes of the Renaissance age, Těšínsko 52, č. 4, 1-10.

- 2009b: Těšínští Piastovci renesančního věku. Životní osudy rodiny knížete Václava III. Adama (1524-1579), rigorózní práce ulož. na FF MU, Brno.

-2010: „I v paměti máme, když jsi o téhož opata orlovského na Hradě pražském s námi austně mluvil...“. $\mathrm{K}$ sekularizaci církevních majetků na Těšínsku v počátcích reformace. In: Trzysta lat tolerancji na Śląsku Cieszyńskim. W trzystulecie założenia kościoła Jezusowego w Cieszynie, 36-65. Cieszyn. 
- 2012: Heslo B 14. 1. Anonym. Pohled na Frýdek a Místek. In: Šopák, P. et al., Město - zámek - krajina. Kulturní krajina českého Slezska od středověku po první světovou válku, 154-155. Opava.

- 2012a: Uherská šlechta a slezští Piastovci na počátku raného novověku (rodové aliance ve víru politiky a osobní prestiže). In: Šl’achta na Kysuciach a jej susedia - Šlechta na Kysucích a její sousedé (Pindur, D.Turóci, M. a kol., edd.), 113-144. Čadca - Český Těšín - Žilina.

- 2014: Počátky města Frýdku do roku 1434. In: Frýdek-Místek. Historie - Kultura - Lidé (Adamec, T. a kol., edd.), 32-41. Praha.

- 2014a: Frýdek na sklonku středověku a v raném novověku (1434-1648). In: Frýdek-Místek. Historie Kultura - Lidé (Adamec, T. a kol., edd.), 49-82. Praha.

JUCHELKA, J., 2004: Frýdek-Místek, ulice Hluboká. Výstavba supermarketu Kaufland. Rkp. nálezové zprávy, NPÚ ÚOP v Ostravě.

- 2004a: Frýdek-Místek (okr. Frýdek-Místek). Supermarket Kaufland, PV 45, 156-157, 197.

- 2006: Záchranný archeologický výzkum ve Frýdku-Místku, Badania archeologiczne na Górnym Śląsku i ziemiach pogranicznych w latach 2003-2004, 233-235.

JUŘÁK, P., 2002: Pamětihodnosti města Frýdku-Místku. Frýdek-Místek.

- 2011: Frýdek-Místek. Praha - Litomyšl.

KAMIŃSKI, R., 2011: Kafel Hansa Bermana z rynku Starego Miasta w Kamieniu Pomorskim - Hans Berman's stove tile from the Old Town market in Kamień Pomorski, Materiały Zachodniopomorskie, Nowa Seria VIII, z. 1: Archeologia, 309-315.

KOLÁ̌̌, F., 2006: Záchranné výzkumy na ulici Hluboké ve Frýdku-Místku, Badania archeologiczne na Górnym Śląsku i ziemiach pogranicznych w latach 2003-2004, 236-239.

KOTÁSEK, J., 2008: Nejstarší dějiny Frýdku. Frýdek-Místek.

KORBELÁŘOVÁ, I.-ŽÁČEK, R., 2008: Těšínsko - země Koruny české / Ducatus Tessiensis - terra Coronae Regni Bohemiae. K dějinám knížectví od počátku do 18. století. Český Těšín.

KOUŘIL, P., 1983: Stř̌edověké nálezy z frýdeckého zámku (okr. Frýdek-Místek), PV 1981, 56.

KOUŘIL, P.-PRIX, D.-WIHODA, M., 1997: Městské hrady v českém Slezsku - Stadtburgen in Böhmisch-Schlesien, AH 22, 249-272.

- 2000: Hrady českého Slezska. Brno - Opava.

KOUŘILOVÁ, M., 2002: Frýdecké panství v urbářích pořízených urbariální komisí roku 1770, Těšínsko 45, č. 3, 15-22.

KOVÁČIK, P.-VESELÁ, B., 2009: Stove tiles from Starý Bohumín - Kachle ze Starého Bohumína Die Kachlen von Starý Bohumín, Studies in Post-Medieval Archeology 3, 289-301.

KOTÁSEK, J., 2008: Nejstarší dějiny Frýdku. Frýdek-Místek.

KRASNOKUTSKÁ, T., 2005: Středověké a novověké kachle z Opavy. Katalog nálezů z archeologických výzkumů. Archaeologiae regionalis Fontes 8. Olomouc.

KROČEK, M., 2002: Fojti na frýdeckém panství, Těšínsko 45, č. 4, 1-9.

KRUŤOVÁ, M., 1998: Kachlový soubor ze zámku ve Frýdku-Místku, rkp. nepubl. bakalářské diplomové práce na FPF Slezské univerzity v Opavě, ved. práce doc. PhDr. P. Kouřil, CSc.

LACHOVÁ, V., 2015: Gotická a renesanční architektura města Frýdku-Místku - Gothic and Renaissance Architecture of the town Frýdek-Místek, rkp. nepubl. bakalářské práce na UP v Olomouci, ved. práce Mgr. Petr Čehovský, Ph.D.

LOSKOTOVÁ, I., 2008: Ornament na kachlích. In: Krása, která hřeje. Výběrový katalog gotických a renesančních kachlů Moravy a Slezska - Schönheit, die wärmt. Gotische und renessainzeitliche Kacheln aus Mähren und Schlesien (Menoušková, D.-Měřínský, Z., edd.), 139-155. Uherské Hradiště.

- 2009: Ornament v kachlovém reliéfu středověkého a raně novověkého Brna. In: Křížová, A. a kol., Ornament - oděv - šperk. Archaické projevy materiální kultury. Etnologické studie 5, 9-27. Brno.

- 2009a: Středověké reliéfní kachle jako pramen hmotné kultury (Morava) - Mittelalterliche Reliefkacheln als Quelle für die materielle Kultur (Mähren), AH 34, 189-208.

- 2011: Brněnské kamnové kachle období gotiky - Brno Stove Tiles in the Gothic Period, rkp. nepubl. disertační práce na ÚAM FF MU, Brno, vedoucí práce doc. PhDr. R. Krajíc, CSc.

- 2014: Kachlový soubor z areálu cisterciáckého kláštera ve Žd’áru nad Sázavou, VVM LXVI - suppl. 2 , 82-103.

MAJEWSKI, M., 2015: Renesansowe kafle zachodniopomorskie. Studium z historii ogrzewania wnętrz mieszkalnych. Stargard - Szczecin.

MENOUŠKOVÁ, D., 2003: Málo známá kolekce reliéfně zdobených pozdně středověkých kachlů z Dambořic - Eine wenig bekannte Kollektion von Kacheln mit Reliefverierungen aus Dambořice, Slovácko XLIV, 183-223. 
- 2008: Portrétní kachle. In: Krása, která hřeje. Výběrový katalog gotických a renesančních kachlů Moravy a Slezska - Schönheit, die wärmt. Gotische und renessainzeitliche Kacheln aus Mähren und Schlesien (Menoušková, D.-Měřínský, Z., edd.), 73-88. Uherské Hradiště.

- 2008a: Fantaskní, mytologické a alegorické motivy. In: Krása, která hřeje. Výběrový katalog gotických a renesančních kachlů Moravy a Slezska - Schönheit, die wärmt. Gotische und renaissancezeitliche Kacheln aus Mähren und Schlesien (Menoušková, D.-Měřínský, Z., edd.), 38-55. Uherské Hradiště.

MOTYLEWSKA, I., 2008: Renesansowe kafle z zamku w Inowłodzu. Łódź.

MÜLlER, K.-ZEZULA, M., 2014: Heslo B1-2. Kamnový kachel s orlicí. In: Matejko-Peterka, I. a kol., Země a její pán. Struktury vlády a její projevy na území Rakouského Slezska do konce první světové války, 57. Opava.

- 2014a: Heslo B1-16. Kamnový kachel s habsburským orlem. In: Matejko-Peterka, I. a kol., Země a její pán. Struktury vlády a její projevy na území Rakouského Slezska do konce první světové války, 81. Opava.

PAJER, J., 1983: Počátky novověké keramiky ve Strážnici. Strážnice.

PASTOREK, R., 2011: O počátcích obcí v povodí řek Morávky a Mohelnice. Současný stav vědění. In: Sborník Státního okresního archivu ve Frýdku-Místku 12, 7-15. Frýdek-Místek.

PAVLÍK, Č.-VITANOVSKÝ, M., 2004: Encyklopedie kachlů v Čechách, na Moravě a ve Slezsku. Ikonografický atlas reliéfů na kachlích gotiky a renesance. Praha.

PINDUR, D., 2004: Těšínsko za vlády těšínského knížete Kazimíra II. (1477-1528), Práce a studie Muzea Beskyd - společenské vědy 14, 1-93.

- 2005: Vznik panského dvora v Sedlištích. In: Sborník Státního okresního archivu ve Frýdku-Místku 6, 10-18. Frýdek-Místek.

- 2014: Frýdek a Místek v letech 1648-1780. In: Frýdek-Místek. Historie - Kultura - Lidé (Adamec, T. a kol., edd.), 104-146. Praha.

SOBOTÍK, B.-GROBELNÝ, A., 1953: Urbář panství frýdecko-místeckého z r. 1580. Opava.

SOUKUP, M. B.-SOUKUPOVÁ, M.-ŠREJBR, A., 2012: Bohemian finds of stove tiles with the signature „HANS BERMAN“ - Kachle se signaturou „Hans Berman“ z českých nálezů - Ofenkacheln mit der Signatur „HANS BERMAN” unter den böhmischen Funden, Studies in Post-Medieval Archaeology 4, 145-164.

TICHÁNEK, J., 2005: Šlechtická sídla na Frýdecko-Místecku. Kopřivnice.

TURKOVÁ, M., 2005: Těšínská knížata a Pernštejnové v polovině 16. století (Edice listů knížete Václava Těšínského Vratislavu z Pernštejna z let 1565-1575), Východočeský sborník historický 12, 15-44.

TYMONOVÁ, M., 2011: Gotické a renesanční kachle ze slezských hradů - Gothic and Renaissance Tiles from Silesian Castles, rkp. nepubl. disertační práce na ÚAM FF MU, Brno. Díl I.-III., vedoucí práce doc. PhDr. P. Kouřil, CSc.

- 2012: Renesanční kachle s dvanácti biblickými hrdiny a tyrany z českého Slezska - Renaissancekacheln mit zwölf biblischen Helen und Tyranen vom tschechischen Gebiet Schlesiens, AH 37, 679-690.

- 2015: Medailonové kachle z Javorníka Medailonové kachle z Javorníka - Die Medaillonkacheln aus Javorník, AH 40, 941-959.

ULIČNÝ, M., 2005: Neskororenesančné kachlice z hradu L'ubovňa. In: Gotické a renesančné kachlice v Karpatoch (Chovanec, J., ed.), 241-251. Trebišov.

VITANOVSKÝ, M., 2008: Heraldické motivy. In: Krása, která hřeje. Výběrový katalog gotických a renesančních kachlů Moravy a Slezska - Schönheit, die wärmt. Gotische und renaissancezeitliche Kacheln aus Mähren und Schlesien (Menoušková, D.-Měřínský, Z., edd.), 90-115. Uherské Hradiště.

VOJKOVSKÁ, E., 2012: Heslo B 14. Frýdek. In: Šopák, P. et al., Město - zámek - krajina. Kulturní krajina českého Slezska od středověku po první světovou válku, 154. Opava.

VOJKOVSKÝ, R., 2007: Frýdek. Zámek ve Frýdku-Místku. Frýdek-Místek.

VÝTISK, S., 2012: Obsazování zemských úřadů na Opavsku v posledních letech vlády Rudolfa II. - The process of appointing the land offices in duchy of Opava in the last years' reign of Rudolf II., Studia historica Brunensia 59, 31-77.

WEISSBROD, M., 2009: Frýdecký zámek. Frýdek-Místek.

ZEZULA, M., 2014: Nejstarší osídlení Frýdecko-Místecka. In: Frýdek-Místek. Historie - Kultura - Lidé (Adamec, T. a kol., edd.), 13-28. Praha.

ŽÁČEK, R., 1986: Pobeskydí od husitství do Bílé Hory. Frýdek-Místek.

- 1992: Těšínsko od roku 1450 do vymření Piastovců. In: Nástin dějin Těšínska, 31-44. Ostrava - Praha.

- 1995: Urbář panství frýdeckého z roku 1636, Těšínsko 38, č. 3, 1-4.

- 1998: K úloze slezských vévodů u lucemburského panovnického dvora. In: Slezsko v dějinách českého státu. Sborník příspěvků z vědecké konference, pořádané pod záštitou prezidenta České republiky Václava Havla u příležitosti 50. výročí Slezského ústavu SZM v Opavě, 150-157. Opava. 
ŽEGKLITZ, J., 2012: Grafické a další předlohy motivů na kachlích z českého prostředí. Renesanční kachle jako prostředek šíření idejí a kultury doby reformace - Prints and other artwork models for motifs on stove tiles in Bohemia. Renaissance stove tiles as an agent in the spread of Reformation ideas and culture, AR LXIV, 265-319.

- 2012a: Prints and other artwork models for motifs on stove tiles from the Czech lands. Renaissance stove tiles as a means for disseminating ideas and culture durinh the age of Reformation, Studies in Post-Medieval Archeology 4, 25-112.

ŽEGKLITZ, J.-VITANOVSKÝ, M.-ZAVŘEL, J., 2009: Soubor kachlových forem z pražské hrnčířské dílny Adama Špačka a její kachlová produkce v letech 1531-1572 - An assemblage of stove tile moulds from the Prague pottery workshop of Adam Špaček and the tile production of this facility in the years 1531-1572, AR LXI, 427-466.

\section{Zusammenfassung}

\section{Die Kachelkollektionen aus Frýdek}

Im vorliegenden Beitrag werden zwei Kachelkomplexe aus dem im ehemaligen Herzogtum Teschen gelegenen schlesischen Friedek (Frýdek) vorgestellt (Abb. 1). Das erste Konvolut stammt aus dem Areal des von den Teschener Piasten in den Jahren 1327-1339 am rechten Ufer der Ostrawitza (Ostravice) erbauten Schlosses (Abb. 2), in dessen östlichem Vorfeld das Städtchen heranwuchs (Abb. 3); die zweite Kollektion wurde an ihrem Nordrand gefunden.

Von dem Schloss gibt es zwei Kachelkollektionen, die in den Jahren 1975 und 1995 während den Arbeiten zur Neugestaltung des ersten Hofes von den Mitarbeiterinnen des Beskiden-Museums aus dem Burggraben gehoben wurden, der vor dem in den Jahren 1638-1644 erfolgten Bau des Oppersdorfer Flügels zugeschüttet worden war (Abb. 4, 5:1, 2). Die zweite Kollektion wurde im Jahr 2003 von den Mitarbeiterinnen der Fachstelle des Nationalen Denkmalinstitus in Ostrava an der Nordseite der Stadt unterhalb des Schlosshügels geborgen (Abb. 5:3). Im Raum zwischen der Masaryk-Allee und den Straßen Hluboka und Na Blatnici wurden von ihnen Abfallgruben mit der Abfalldeponie einer Töpferei freigelegt, und in weiteren Objekten hat man Kacheln mit Gebrauchsspuren gefunden. Da in beiden Kollektionen Kacheln mit identischer Verzierung vorkamen, ist es möglich, dass sie in der Töpferei hergestellt worden sein können, zu der die Deponie gehörte. Diese Hypothese hat sich jedoch nicht ganz bestätigt, da die gefundenen Kacheln Gebrauchsspuren aufwiesen (Ruß, Lehmbewurf) und an der Stelle keine nachweisbaren Belege für eine Kachelproduktion festgestellt wurden („Halbfabrikate“, beschädigte Erzeugnisse, Tiegel oder Produktionsobjekte).

Die auf den aus beiden Kollektionen stammenden Kacheln vorkommende identische Verzierung besteht aus einem ungekrönten Adler im Perlenstab, der auf der Brust ein Wappen mit dem sog. Babenberger Balken hat (Abb. 6:1-3). Gemäß der künstlerischen Gestaltung und dem jüngeren Hals werden sie in die Zeit um Mitte des 16. Jahrhunderts datiert. Zu diesem Zeitraum bekennen sich auch Kacheln mit den Jahreszahlen 1545 (?) und 1548 (Abb. 7:1-3), die mit der Vormundschaftsherrschaft von Johann von Pernstein $(\dagger 1548)$ zusammenhängen, der in den Jahren 1528-1545 das Herzogtum Teschen für den minderjährigen Herzog Wenzel III. Adam $(† 1579)$ verwaltete. Seine Sympathie für die protestantische Bewegung wird auf Kacheln mit reformatorischen Motiven symbolisiert. Zu ihnen gehört auch ein Bruchstück mit Gideon aus dem Zyklus der zwölf alttestamentarischen Helden (1531), das auch in Schlesisch Ostrau und in Bruntál gefunden wurde (im vorliegenden Sammelband des Jahres 2012 veröffentlicht). Im Bruntáler Konvolut kamen zusammen mit dem identischen Gideon auch Bruchstücke vor, die mit geflochtenen Blättern des Granatapfelbaumes verzierte Arkaden aufwiesen wie sie für Kacheln aus der Werkstatt von Hans Berman typisch sind. Der reformatorische Einfluss ist auch auf weiteren Kacheln aus der zweiten Hälfte des 16. Jahrhunderts zu erkennen, die einen mit Martin Luther identifizierten Mann zeigen, der ein Buch liest (Abb. 7:4), desweiteren ein Porträt der dänischen Königin Isabelle von Habsburg mit der Aufschrift „DENEMAR“ und dem Torso des 
sächsischen Wappens mit Greif sowie das Porträt eines vollbärtigen Adeligen unter der Kassette einer Archivolte (Abb. 7:6).

Neben Kacheln mit religiöser Thematik gehört ein mit einem Tannenzapfenkranz gerahmter Greif (Abb. 8:1), ein Landsknecht mit Hellebarde und Schwert (Abb. 8:2), eine von Weintrauben umsäumte Rosette (Abb. 8:3) und verschiedene Simskacheltypen mit vegetabilen und architektonischen Mustern (Abb. 8:4-6) zum älteren Horizont der Schlossfunde aus der ersten Hälfte des 16. Jahrhunderts. In die von der Architektur aus der Zeit nach Mitte des 16. Jahrhunderts beeinflusste Motivserie fallen auch quadratische und rechteckige Spiegelkacheln mit freier oder verzierter Mittelfläche (Abb. 9:1-4), wobei einige dieser Kacheln noch einen halbzylinderförmigen Hals haben. In den gleichen Zeitraum gehören auch Kacheln mit zentralen Eintiefungen und bauchigen Medaillons, die zusätzlich sternförmige Ornamente aufweisen (Abb. 9:5, 6).

Eine weitere Kachel, die in beiden Kollektionen vorkam, enthielt ein Relief des gekrönten doppelköpfigen Kaiseradlers mit Schwert und Apfel. Die unglasierte Kachelhälfte fand man auf dem Schloss (Abb. 10:1), und aus einer Abfallgrube unter dem Schlosshügel wurde ein komplettes, grün glasiertes Pendant dazu gehoben (Abb. 10:2). Ebenso wie der Adler werden die übrigen Kacheln mit habanischen Tapetenmustern in den Zeitraum zwischen der zweiten Hälfte des 16. und dem Beginn des 17. Jahrhunderts datiert, wie etwa eine Kachel mit herzförmigem Bandmuster und Weintrauben (Abb. 10:3), die ebenfalls im Schlossgraben gefunden wurde (Abb. 10:4), sowie eine Kachel mit Arabeskenmotiven, die sich an der Wende des 16. und 17. Jahrhunderts aus Akanthusblättern und Palmetten herausgebildet hatten (Abb. 10:5, 6).

Tapetenornamente sind in unsere Kachelproduktion mittels originalen Habaner-Erzeugnissen vorgedrungen, die ab Mitte des 16. Jahrhunderts von den heimischen Töpfern nachgeahmt wurden, worauf eine Matrize aus der Prager Schreinergasse (Truhlářská) hindeutet, welche die Jahreszahl 1554 trägt. In dem Schlosskonvolut gehörten auch Kacheln mit kreisförmigen Mustern zu dieser Gruppe (Abb. 11:1, 2), die auch als Eckkachelvarianten erhalten geblieben sind (Abb. 11:3). Ferner handelte es sich um Kacheln mit sog. angeschlagenem Bandornament (Abb. 11:4) und um Exemplare mit ovalem Ornament und Lilienpalmetten (Abb. 11:5, 6). Außer geometrischen und vegetabilen Elementen kam auch der Kaiseradler in der Verzierung der Tapetenkacheln vor (Abb. 11:7). Ab der zweiten Hälfte des 16. Jahrhunderts stellte man Kacheln mit runden Bandmedaillons her, die mit stilisierten Pflanzen gefüllt waren (Abb. 8, 9).

Die vom Friedeker Schloss und aus dem Bereich am Nordrand des historischen Stadtkerns stammenden Kacheln stellen eine wertvolle Kollektion dar, deren Datierung sich grob mit den baulichen Veränderungen des ursprünglich landesherrlichen Sitzes, der ab 1573 ein Adelssitz war, deckt. Die ältesten Exemplare fallen in den Zeitraum um 1500, bzw. in das erste Drittel des 16. Jahrhunderts, als Herzog Kasimir II. von Teschen die Burg modernisieren ließ. Die Renaissanceumbauten werden durch Kacheln dokumentiert, die Jahreszahlen aufweisen und deren Entstehung mit der Vormundschaftsherrschaft der Pernsteins und mit Herzog Wenzel III. Adam zusammenhing, der reformatorischen Ideen zugeneigt war, was auch in der Ikonographie des Kachelmaterials zum Ausdruck kam. In der zweiten Hälfte des 16. Jahrhunderts drangen Kachelöfen auch in bürgerliche Interieurs vor, worauf eine Kachel mit Adler hindeutet, die unterhalb des Schlossplatzes in einer Abfallgrube entdeckt wurde, wo sich die Häuser der herrschaftlichen Beamten befanden, welche die Verwaltung der Herrschaft unter sich hatten. Öfen mit Tapetenmustern wurden in der zweiten Hälfte des 16. Jahrhunderts und zu Beginn des daran anschlieBenden Jahrhunderts auf dem Schloss und auch in der Stadt installiert, als Friedek sich im Besitz der Familie von Würben und Freudenthal und danach in dem der Familie von Oppersdorf befand. Die Tatsache, dass in beiden Kollektionen identische Einzelstücke vertreten sind, ist ein Beleg dafür, dass sich auch Angehörige aus den Reihen der Beamten- und Bürgerelite ähnliche Öfen wie auf dem Schloss leisten konnten und dass auch im aristokratischen Schlossmilieu Ofenkörper sowohl in der teureren glasierten als auch in der billigeren unglasierten Ausführung gesetzt wurden. Ihre Herstellung erfolgte offenbar in einer Töpferei an der Stadtmauer unterhalb des Schlosses, wofür nachweisbare Belege jedoch bislang fehlen. 
PhDr. et PhDr. Markéta Tymonová, Ph.D., Ústav archeologie Filozoficko-přírodovědecké fakulty Slezské univerzity v Opavě, 74601 Opava, Česká republika, marketa.tymonova@fpf.slu.cz 
